\title{
Hydrogen Peroxide and Amyotrophic Lateral Sclerosis: From Biochemistry to Pathophysiology
}

\author{
Nitesh Sanghai ${ }^{1, *(1)}$ and Geoffrey K. Tranmer ${ }^{1,2}$ (1)
}

1 College of Pharmacy, Rady Faculty of Health Science, University of Manitoba, Winnipeg, MB R3E 0T5, Canada; geoffrey.tranmer@umanitoba.ca

2 Department of Chemistry, Faculty of Science, University of Manitoba, Winnipeg, MB R3T 2N2, Canada

* Correspondence: sanghain@myumanitoba.ca; Tel.: +1-431-338-0385

Citation: Sanghai, N.; Tranmer, G.K. Hydrogen Peroxide and

Amyotrophic Lateral Sclerosis: From Biochemistry to Pathophysiology. Antioxidants 2022, 11, 52. https:// doi.org/10.3390/antiox11010052

Academic Editor: Stanley Omaye

Received: 19 November 2021

Accepted: 24 December 2021

Published: 27 December 2021

Publisher's Note: MDPI stays neutral with regard to jurisdictional claims in published maps and institutional affiliations.

Copyright: (C) 2021 by the authors. Licensee MDPI, Basel, Switzerland. This article is an open access article distributed under the terms and conditions of the Creative Commons Attribution (CC BY) license (https:// creativecommons.org/licenses/by/ $4.0 /)$.

\begin{abstract}
Free radicals are unstable chemical reactive species produced during Redox dyshomeostasis $(\mathrm{RDH})$ inside living cells and are implicated in the pathogenesis of various neurodegenerative diseases. One of the most complicated and life-threatening motor neurodegenerative diseases (MND) is amyotrophic lateral sclerosis (ALS) because of the poor understanding of its pathophysiology and absence of an effective treatment for its cure. During the last 25 years, researchers around the globe have focused their interest on copper/zinc superoxide dismutase $(\mathrm{Cu} / \mathrm{Zn}$ SOD, SOD1) protein after the landmark discovery of mutant SOD1 (mSOD1) gene as a risk factor for ALS. Substantial evidence suggests that toxic gain of function due to redox disturbance caused by reactive oxygen species (ROS) changes the biophysical properties of native SOD1 protein thus, instigating its fibrillization and misfolding. These abnormal misfolding aggregates or inclusions of SOD1 play a role in the pathogenesis of both forms of ALS, i.e., Sporadic ALS (sALS) and familial ALS (fALS). However, what leads to a decrease in the stability and misfolding of SOD1 is still in question and our scientific knowledge is scarce. A large number of studies have been conducted in this area to explore the biochemical mechanistic pathway of SOD1 aggregation. Several studies, over the past two decades, have shown that the SOD1-catalyzed biochemical reaction product hydrogen peroxide $\left(\mathrm{H}_{2} \mathrm{O}_{2}\right)$ at a pathological concentration act as a substrate to trigger the misfolding trajectories and toxicity of SOD1 in the pathogenesis of ALS. These toxic aggregates of SOD1 also cause aberrant localization of TAR-DNA binding protein 43 (TDP-43), which is characteristic of neuronal cytoplasmic inclusions (NCI) found in ALS. Here in this review, we present the evidence implicating the pivotal role of $\mathrm{H}_{2} \mathrm{O}_{2}$ in modulating the toxicity of SOD1 in the pathophysiology of the incurable and highly complex disease ALS. Also, highlighting the role of $\mathrm{H}_{2} \mathrm{O}_{2}$ in ALS, we believe will encourage scientists to target pathological concentrations of $\mathrm{H}_{2} \mathrm{O}_{2}$ thereby halting the misfolding of SOD1.
\end{abstract}

Keywords: motor neurodegenerative disease; amyotrophic lateral sclerosis; superoxide dismutase 1; mutant superoxide dismutase 1; reactive oxygen species; hydrogen peroxide; misfolding; aggregation; fibrilization; redox dyshomeostasis; TAR-DNA binding protein 43; neuronal cytoplasmic inclusions

\section{Introduction}

Free radicals, in the context of living cells, are bio-reactive species. They are unstable, short-lived, and highly reactive chemical species. They react with various biological molecules to complete the quest for their electrons to become stable [1]. Free radicals have implications in diverse kinds of neurodegenerative diseases like ALS [2], Alzheimer's disease (AD) [3], Parkinson's disease (PD) [4], Huntington's disease(HD) [5]. ALS is one of the most devastating and highly complex neurodegenerative diseases. Disease progression is usually rapid, and the average survival is only 2-3 years from symptom onset. Despite intense research, the cause of the disease is still unknown, and the etiology of motor neurodegeneration (MND) is still incompletely understood. The development of new therapies is hindered, because of the poor understanding of the molecular mechanism and 
biological process associated with the disease. ALS is a multifactorial disease, with multiple genetic and environmental factors playing an important role in disease pathology [6]. Out of all the ALS cases known, around $20 \%$ of familial MND cases (5-10\% of all cases are familial) are caused by mutations in a ubiquitous metalloenzyme called SOD1 [7]. The other $90 \%$ of cases are sporadic in nature and termed sALS. The discovery of mutations in the superoxide dismutase 1 (SOD1) gene that encodes antioxidant SOD1 enzyme, made it possible to understand the progression of the disease. Substantial evidence has shown that abnormal conformational change in the structure of SOD1 protein causes misfolding and aggregation, and thus is thought to have neurotoxic properties, which are observed in both forms of ALS [8-10]. It's has been more than two decades after the landmark discovery of mutant SOD1 (mSOD1) [7], and scientists are still trying to untangle the mystery behind the misfolding of SOD1. A large body of evidence has shown that redox dysregulation of SOD1 during oxidative stress is largely involved in changing the biochemical and biophysical properties of SOD1 causing its abnormal aggregation and misfolding [11-16], which is evident in the cellular toxicity observed in ALS [17-20]. Studies have shown that hydrogen peroxide $\left(\mathrm{H}_{2} \mathrm{O}_{2}\right)$ modulates the redox state of SOD1, controlling the folding and misfolding of SOD1. The abnormal conformational kinetic change in the SOD1 structure is due to the increased concentration of $\mathrm{H}_{2} \mathrm{O}_{2}$, culminating in motor neuron death in ALS [21-25]. Furthermore, toxic SOD1 has been found to modulate TDP-43 localization from the cytoplasm to the nucleus. Abnormal oligomerization of SOD1 causes mislocalization of TDP-43 leading to unusual accumulation in the cytosol, thus causing the gain of a new pathogenic function observed in the degeneration of motor neurons of ALS [21,26-28]. Herein, we explore the role of $\mathrm{H}_{2} \mathrm{O}_{2}$ as a major determinant in the pathophysiology of ALS.

\section{Bio-Reactive Oxygen Species in Living Cells}

Free radicals are chemically reactive species, having an electrophilic nature, Refs. [29,30] as a result of an unpaired electron in their outermost orbital. Because of these unpaired electrons, they are highly unstable and reactive and are continuously produced in vivo [31]. They also act as a vital molecule for the existence of life on earth and regulate the metabolism of cells and take part in the generation of ATP for the survival of cells [31-33]. Although it is important for life, molecular oxygen $\left(\mathrm{O}_{2}\right.$, also termed triplet oxygen) is a biradical and unstable molecule with two unpaired electrons with parallel spins in the same direction in its outer orbital and thus paramagnetic character [34]. The presence of two unpaired electrons with unpaired spin and high resonance stabilization energy of the $\pi$ electron [34] decreases the reactivity of $\left(\mathrm{O}_{2}\right)$ showing its dynamic "quantum quirkiness" [35] with other biomolecules of life, which has a normal configuration with a paired electron in the outermost orbital with opposite spins. Thus, the stable nonradical molecule must undergo spin inversion to donate an electron to molecular oxygen, which is restricted and against the law of quantum mechanics [32]. To overcome this chemical barrier, oxygen molecule reacts with paramagnetic transition metals like iron $(\mathrm{Fe})$ and copper $(\mathrm{Cu})$, which are found primarily in biomolecules or there is successive addition of electrons to the molecular oxygen during cellular metabolism. The reduction of univalent molecular oxygen mainly takes place in mitochondria with the help of cytochrome c oxidase (Complex IV), during oxidative phosphorylation and leads to the addition of four electrons to $\mathrm{O}_{2}$ to reduce it to $\mathrm{H}_{2} \mathrm{O}$ (Figure 1). This means that $\mathrm{O}_{2}$ is ultimately reduced to water $\left(\mathrm{H}_{2} \mathrm{O}\right)$ by producing the intermediate radicals, such as superoxide anion radical $\left(\mathrm{O}_{2}{ }^{\bullet-}\right), \mathrm{H}_{2} \mathrm{O}_{2}$, and hydroxyl radical $\left(\mathrm{HO}^{\bullet}\right)$. Out of these $\left(\mathrm{O}_{2}{ }^{\bullet-}\right)$ and $\mathrm{HO}^{\bullet}$ are highly reactive free radicals and react with organic biomolecules, leading to the production of other intermediates and thus produce free radicals, creating oxidative stress and ROS inside living cells, disrupting the normal redox biology of living cells [36,37]. In addition, Coenzyme Q (CoQ) is an essential, lipid-soluble component of the mitochondrial membrane electron transport chain (ETC) and, it has been reported that the semiquinone radical generated from human antioxidant coenzyme $Q$ (Q10) can lead to an increase in $\left(\mathrm{O}_{2}{ }^{-}-\right)$in humans [38,39], due to the abnormal dysfunction of mitochondrial ETC. This change in bioenergetics of mitochondrial ETC leads to higher 
production of $\left(\mathrm{O}_{2}{ }^{\bullet-}\right)$ in cells [40,41]. Biomolecules like membrane phospholipids [42], mitochondrial DNA [43], proteins, peptides, sulfur-containing amino acids like methionine (Met), and cysteine (Cys) contain highly nucleophilic reactive functional groups, such as sulfhydryl or thiols ( $\mathrm{SH}$ ) are vulnerable to be oxidized by excessive ROS [44]. For instance, SOD1 protein undergoes misfolding due to a conformational change caused by the excessive irreversible oxidation of $(\mathrm{SH})$ group to sulfinic acid $\left(-\mathrm{SO}_{2} \mathrm{H}\right)$ and sulfonic acid $\left(-\mathrm{SO}_{3} \mathrm{H}\right)$ modifications however, the first step in the oxidation of the $(\mathrm{SH})$ group to sulphenic acid (-SOH) remains reversible and gives rise to the formation of a disulfide bond (-S-S-) [45]. Therefore, the balance between oxidation-reduction (redox) processes, is an evolutionarily conserved process in the biological system and is maintained by the presence of efficient reductase enzymes. Further, the (-S-S-) can be salvaged for SOD1 by the presence of efficient reductants. However, under various cellular stress condition, oxidative stress cause abnormal oxidative PTMs and leads to change in protein biochemistry as indicated. Thus, the living cells maintain a redox balance between biological natural reductants and oxidants to maintain homeostasis inside the living cells for their survival [46-48].

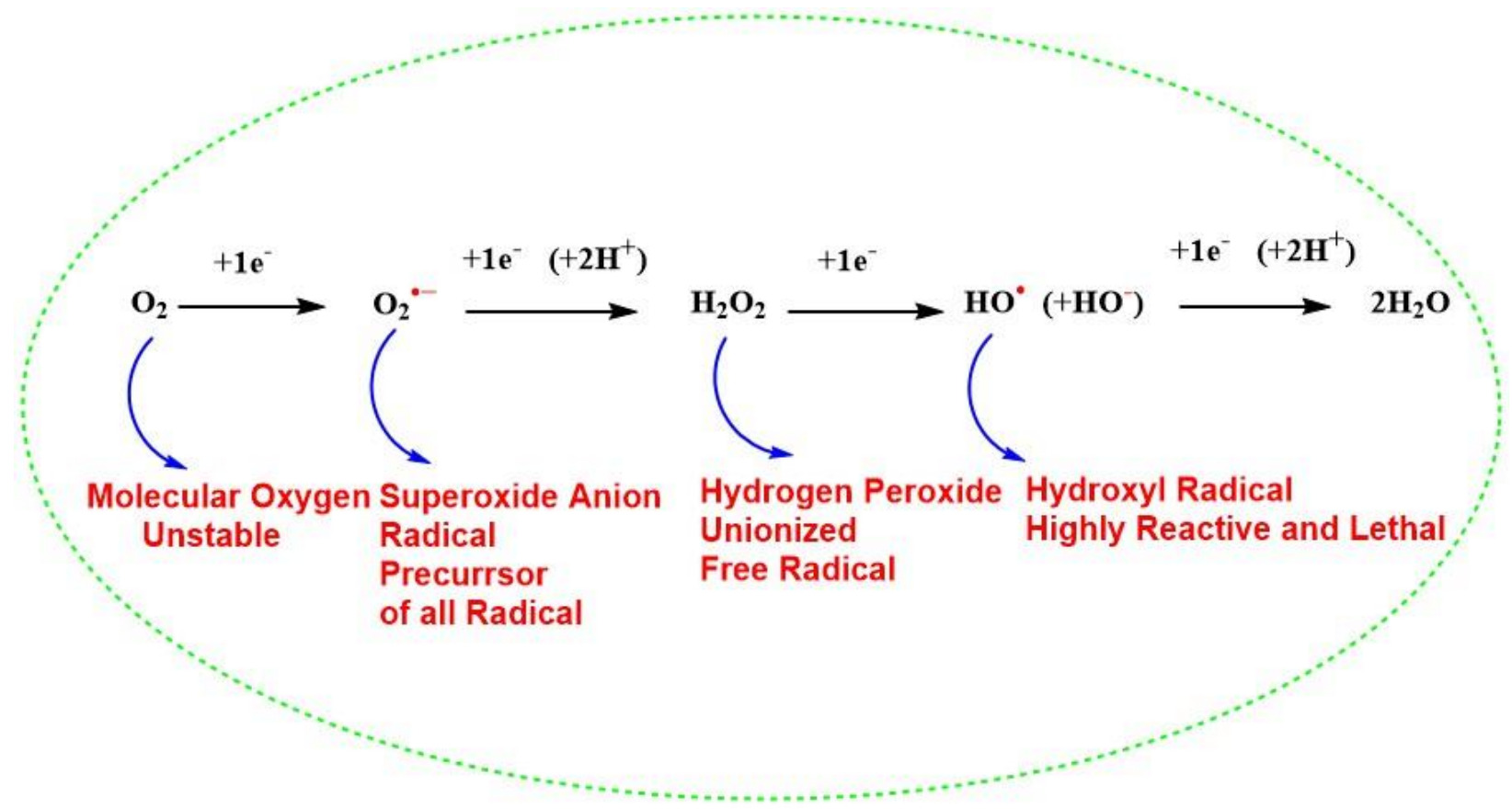

Figure 1. Successive four-electron reduction of molecular oxygen to generate water and different reactive oxygen species during cellular metabolism.

'Oxidative stress' is a term associated with both enhanced production of ROS and reduced efficacy of protection by antioxidant enzymes or reduced molecular weight antioxidants. After the discovery of nitric oxide radical $\left(\mathrm{NO}^{\bullet}\right)$ as a biological signaling molecule [49], it was unraveled that peroxynitrite $\left(\mathrm{ONOO}^{-}\right)$may be formed in vivo from superoxide and nitric oxide to create 'nitrosative stress' and reactive nitrogen species(RNS) [50]. Tyrosine is a common target of nitrosative stress and 3-nitrotyrosine (3-NT) has been detected in various neurodegenerative diseases [51], such as ALS [52], AD [51], and PD [53].

\section{The Chemistry of Hydrogen Peroxide}

$\mathrm{H}_{2} \mathrm{O}_{2}$ is the nonionized 2-electron reduction product of unstable molecular oxygen [54], which plays a central role in maintaining the redox cycle of living cells [55]. $\mathrm{H}_{2} \mathrm{O}_{2}$ is a diverse potent oxidizing and inexpensive chemical molecule, which has chemical applications [56], biological functions [55], and therapeutic applications which include antimicrobial and oxidizing agents [57]. Over the last decade, $\mathrm{H}_{2} \mathrm{O}_{2}$ has been used as a green oxidant and alternate source of oxygen to convert biomass to chemical synthesis [56]. It also acts 
as an environmentally friendly oxidizing catalyst in many oxidizing chemical processes because the end product of its decomposition is only a water molecule [58]. $\mathrm{H}_{2} \mathrm{O}_{2}$ is one of the closest cousins of water and is a non-planar molecule having an open book structure. It is also regarded as the smallest chiral molecule, which can undergo a disproportionation reaction to act both as oxidizing and reducing agent $[59,60]$.

$\mathrm{H}_{2} \mathrm{O}_{2}$ is a strong oxidant, having a reduction potential of $1.76 \mathrm{~V}$ at $\mathrm{pH} 7.0,25^{\circ} \mathrm{C}$. Therefore, it is more oxidizing than hypochlorous acid $(\mathrm{HOCl})$ or $\left(\mathrm{ONOO}^{-}\right)$, for which the reduction potentials are 1.48 and $1.4 \mathrm{~V}$, respectively. However, relative to these two reactive species, the reactivity of $\mathrm{H}_{2} \mathrm{O}_{2}$ is relatively low with various biological molecules like nucleic acid, proteins, and lipids. Further, this can be explained by its higher activation energy barrier, which must be overcome to release its oxidizing power. In other words, the chemical reactions of hydrogen peroxide are kinetically controlled rather than thermodynamically driven [61]. The $\mathrm{H}_{2} \mathrm{O}_{2}$ produced during cellular metabolism is found to be stable, compared to $(\mathrm{HOCl})$ having a half-life in minutes and $\left(\mathrm{ONOO}^{-}\right)$having a half-life of $10^{-3} \mathrm{~s}[1,62]$. It is a major oxidant produced by the activated neutrophils at the site of inflammation from $\mathrm{H}_{2} \mathrm{O}_{2}$ and chloride, catalyzed by the enzyme myeloperoxidase, a leukocyte-derived enzyme. HOCL exerts its oxidizing power through the oxidation and chlorination of biomolecules like nucleic acids, lipids, and cholesterol [63]. It confers its oxidizing power via chlorination of amino acids like tyrosine to form 3-chlorotyrosine and damage the collagen [64]. $\mathrm{HOCl}$ is more reactive than $\mathrm{H}_{2} \mathrm{O}_{2}$ (rate constants of $3 \times 10^{7} \mathrm{M}^{-1} \mathrm{~s}^{-1}$ and $0.9 \mathrm{M}^{-1} \mathrm{~s}^{-1}$, respectively), however, the redox potential for the 2-electron reduction is larger for the $\mathrm{H}_{2} \mathrm{O}_{2}$ in forming $\mathrm{H}_{2} \mathrm{O}$, than for the former in releasing chloride [65]. $\mathrm{ONOO}^{-}$is formed by the reaction between $\mathrm{O}_{2}{ }^{\bullet-}$ and $\mathrm{NO}^{\bullet}$. It is highly toxic to biomolecules, oxidizes lipids, Met, and tyrosine residues in proteins [66]. The nitrotyrosine residues are considered as a marker of $\mathrm{ONOO}^{-}$induced cellular damage, potentially serving as a "peroxynitrite footprint" in the biological oxidation process. The main biological target of $\mathrm{ONOO}^{-}$is DNA, where it oxidizes the base pairs, causing nitrative and oxidative DNA lesions such as 8-nitroguanine and 8-oxodeoxyguanosine respectively [67,68]. Recent evidence has shown that the protein $(\mathrm{SH})$ significantly reacts faster with $\mathrm{ONOO}^{-}$compared to $\mathrm{H}_{2} \mathrm{O}_{2}[69,70]$.

$\mathrm{H}_{2} \mathrm{O}_{2}$ is a weak one-electron oxidant, although the one-electron reduction product, the $\mathrm{HO}^{\bullet}$ is one of nature's most vulnerable bio-reactive species, which can create an oxidizing environment in the living cell and ultimately lead to its death [71-73]. The redox property of $\mathrm{H}_{2} \mathrm{O}_{2}$ is dependent upon the $\mathrm{pH}$ of the solutions, as the $\mathrm{pKa}$ of $\mathrm{H}_{2} \mathrm{O}_{2}$ is 11.6, so it is mostly unionized at physiological $\mathrm{pH}$. The strong nucleophilicity of hydroperoxide nucleophile $(-\mathrm{OOH})$ is limited due to its high $\mathrm{pKa} . \mathrm{H}_{2} \mathrm{O}_{2}$ also acts as electrophile due to the polarization of the peroxide bond $(\mathrm{O}-\mathrm{O})$. The homolytic bond dissociation enthalpies of peroxide in $\mathrm{H}_{2} \mathrm{O}_{2}$ at $298 \mathrm{~K}$ is $50 \mathrm{kcal} / \mathrm{mol}$, whereas the heterolytic bond dissociation enthalpies of $\mathrm{H}_{2} \mathrm{O}_{2}$ is $290 \mathrm{kcal} / \mathrm{mol}$. The unexpected chemical reactivity of hydrogen peroxide is generally attributed to the weakness of $(\mathrm{O}-\mathrm{O})$ and therefore, it is homolytically cleaved in presence of heating, radiolysis, photolysis, or transition metals [74]. Prof. John O. Edwards, a pioneer in the field of peroxide chemistry, has demonstrated the mechanism of peroxide chemistry exquisitely. According to him, thiolates $\left(-S^{-}\right)$are more reactive than $(\mathrm{SH})$. Hence, $\left(-S^{-}\right)$, being nucleophilic, react with $\mathrm{H}_{2} \mathrm{O}_{2}$, an electrophile, by bimolecular nucleophilic substitution (SN2) reaction mechanism displacing ${ }^{-} \mathrm{OH}$ as leaving group [75]. However, recent developments on this mechanism suggest that the by-product of the reaction is $\mathrm{H}_{2} \mathrm{O}$ instead of hydroxyl anion $\left(\mathrm{HO}^{-}\right)$[76,77]. The nucleophilic reaction of a protein $\left(-\mathrm{S}^{-}\right)$on electrophilic $\mathrm{H}_{2} \mathrm{O}_{2}$ forms $\mathrm{H}_{2} \mathrm{O}$ as a by-product and results in the formation of cysteine sulphenic acid (CysSOH), the process is also known as S-sulfenylation. Depending upon the protein microenvironment where the thiolate is located, the reaction is exclusive to $\left(-S^{-}\right)$, and at physiological $\mathrm{pH}$, dependent upon the $\mathrm{pKa}$ values of the sulfur-containing amino acids. In addition, hydrogen bonding also plays an important part in the ionization of (SH) to $\left(-S^{-}\right)$[78-80]. Further, the SN2 paradigm was also challenged and proved by hybrid quantum-classical (QM-MM) molecular dynamics simulations [79]. The nucleophilicity of $\mathrm{H}_{2} \mathrm{O}_{2}$ could be explained by the reaction of ${ }^{-} \mathrm{OOH}$ with organohalides [81], and oxidation 
of boron compounds [82]. We can thus conclude that $\mathrm{H}_{2} \mathrm{O}_{2}$, a green redox molecule that has properties of both oxidant and reductant, also can be a nucleophile and electrophile in chemical reactions. Having all these characteristics it reacts poorly with most biological molecules because of the high activation energy barrier and the reaction rate is kinetically controlled. Thus, the vigorous oxidizing power of $\mathrm{H}_{2} \mathrm{O}_{2}$ comes indirectly from its transition metal catalysis into $\mathrm{HO}^{\bullet}$ by Fenton and Haber-Weiss reactions [61]. In addition, $\mathrm{Cu} / \mathrm{Zn}$ SOD1, which is a ubiquitous natural antioxidant enzyme, is mainly involved in dismutation of ionizable toxic $\mathrm{O}_{2}{ }^{\bullet-}$ radical in vivo to produce a non-ionizable less toxic redox molecule $\mathrm{H}_{2} \mathrm{O}_{2}$, which has the ability to generate $\mathrm{OH}^{\bullet}$ free radical, thereby acting as pro-oxidant in certain disease conditions $[23,83]$.

\subsection{Hydrogen Peroxide as Double Edge Sword in Living Cells}

$\mathrm{H}_{2} \mathrm{O}_{2}$ acts both as a redox signaling molecule and an oxidative stress molecule. As a signal transduction molecule $\mathrm{H}_{2} \mathrm{O}_{2}$ has a role in controlling various key cellular processes like cell shape changes, initiating proliferation, recruitment of immune cells, calcium ion $\left(\mathrm{Ca}^{+2}\right)$ signaling in the lumen of endoplasmic reticulum and mitochondria-associated membranes [54,84]. It acts as a secondary messenger in insulin signaling and several growth factor-induced signaling cascades [54]. Also, $\mathrm{H}_{2} \mathrm{O}_{2}$ is involved in the chemical modifications of specific Cys amino acids, which are expressed in some cellular proteins [85]. $\mathrm{H}_{2} \mathrm{O}_{2}$ generated during physiological oxidative stress conditions in the concentration of around (1-10 $\mathrm{nM})$ acts as a redox signaling molecule in various cellular processes creating oxidative eustress, although, the higher or pathological concentration of $\mathrm{H}_{2} \mathrm{O}_{2}$ of around $(>100 \mathrm{nM})$ is known to cause deleterious effects to cellular biomolecules, this effect is called oxidative distress (Figure 2) [55]. According to many reports, the higher pathological concentration of $\mathrm{H}_{2} \mathrm{O}_{2}$ in oxidative stress conditions can go up to $150 \mu \mathrm{M}$ [86-88].

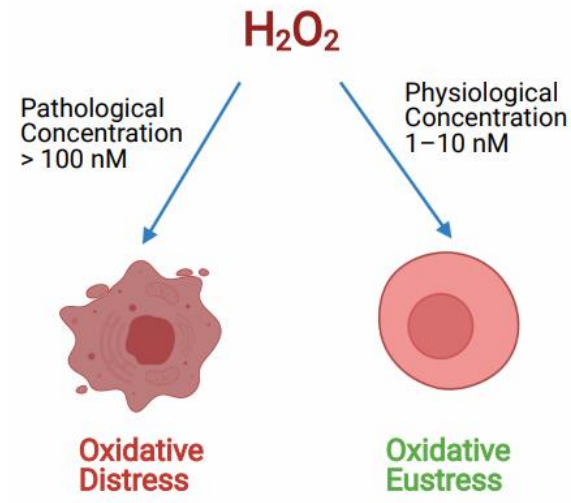

Figure 2. Role of $\mathrm{H}_{2} \mathrm{O}_{2}$ controlling the oxidative redox balance of the cell at different concentrations. Hydrogen peroxide $\left(\mathrm{H}_{2} \mathrm{O}_{2}\right)$ controls the cell signaling process at physiological concentration called oxidative Eustress. Whereas, at pathological concentration, $\mathrm{H}_{2} \mathrm{O}_{2}$ causes cell death due to oxidative distress.

Various studies have been conducted to examine the concentration at which the $\mathrm{H}_{2} \mathrm{O}_{2}$ acts as a cytotoxic and neurotoxic agent. Further, various studies have investigated the mode of cell death caused by $\mathrm{H}_{2} \mathrm{O}_{2}$, mainly due to apoptosis or necrosis [89-91]. It was found that the effects of $\mathrm{H}_{2} \mathrm{O}_{2}$ are largely dependent upon the mode of cell death induced (apoptosis or necrosis) depending on the cell type used, its physiological state, length of exposure to $\mathrm{H}_{2} \mathrm{O}_{2}$, the $\mathrm{H}_{2} \mathrm{O}_{2}$ concentration used, and the cell culture media employed [89,92]. Yoshiro and colleagues (2006) [93], investigated that $50 \mu \mathrm{M}$ of $\mathrm{H}_{2} \mathrm{O}_{2}$ exhibited caspase- 9 and caspase- 3 activation, finally leading to apoptotic cell death in human T-lymphoma Jurkat cells, whereas a higher concentration of $500 \mu \mathrm{M}$ caused necrotic death. Teramoto and the group (1999) [94], demonstrated that a lower concentration of $10-100 \mu \mathrm{M}$ predominantly caused apoptosis, however, a higher concentration of 1-10 mM induced necrosis in human lung fibroblasts cells. Troyano and associates (2003) [95], 
demonstrated caspase- 9 and caspase- 3 activation and death by apoptosis in U-937 human promonocytic cells when treated with $200 \mu \mathrm{M} \mathrm{H}_{2} \mathrm{O}_{2}$. Although, treatment with $2 \mathrm{mM}$ $\mathrm{H}_{2} \mathrm{O}_{2}$ caused necrosis. Gulden and the group (2010) [86], investigated in detail how exposure time and cell concentration affect the cytotoxic potency of $\mathrm{H}_{2} \mathrm{O}_{2}$ in vitro. They investigated those median cytotoxic concentrations decreased from 500 to $30 \mu \mathrm{M}$ with increasing incubation time from 1 to $24 \mathrm{~h}$. The cytotoxic effects of $\mathrm{H}_{2} \mathrm{O}_{2}$ were also evaluated in neuroblastoma $\times$ spinal cord motor neuron cell line (NSC34). A short (30 min) exposure of $\mathrm{H}_{2} \mathrm{O}_{2}$ caused delayed cell death with the median effective concentration $\left(\mathrm{EC}_{50}\right)$ of $\sim 1 \mathrm{mM}$ [96]. Also, treatment of $500 \mu \mathrm{M} \mathrm{H}_{2} \mathrm{O}_{2}$ for $24 \mathrm{~h}$ in a hippocampal neuronal cell line (HT-22) induces around 50\% of cell death [97]. Further, investigation of exposure to $1 \mathrm{mM}$ $\mathrm{H}_{2} \mathrm{O}_{2}$ for $2 \mathrm{~h}$ on human embryonic kidney 293 cells (HEK293) in vitro, cells displayed the extent of programmed cell death, with Condensed chromatin and apoptotic nuclei [98]. The above-reported studies and various other studies [99-103] elucidated $\mathrm{H}_{2} \mathrm{O}_{2}$ concentrationdependent change in cell signaling and death. Very low concentration of $\mathrm{H}_{2} \mathrm{O}_{2}$ cause cell signaling and hence, cell growth, a mid-higher concentration of around (120 $\mu \mathrm{M}$ to $150 \mu \mathrm{M})$ induce a temporary growth arrest, the intermediate concentration of $(250 \mu \mathrm{M}-400 \mu \mathrm{M})$ causes permanent growth arrest and a higher concentration of $(\geq 1 \mathrm{mM})$ causes cell damage by necrosis and hence death.

\subsection{Metabolic Sources and Sinks of Hydrogen Peroxide}

The superoxide anion radical is the precursor of all radicals, and it is generated during the respiratory electron transport chain process complexed with cytochrome I, II, and III or by NAD(P)H oxidases (NOXs) enzymes in the mitochondria [104]. A total of $31 \mathrm{H}_{2} \mathrm{O}_{2}$ generating oxidases have been reported [105]. SODs like SOD1, SOD2, SOD3, with their presence in cytosolic, mitochondrial matrix, and extracellular locations, respectively are the major sources of $\mathrm{H}_{2} \mathrm{O}_{2}$. Besides that, the endoplasmic reticulum and peroxisomes are also responsible for the production of $\mathrm{H}_{2} \mathrm{O}_{2}$ [55]. There exist an $\mathrm{H}_{2} \mathrm{O}_{2}$ gradient, which is largely associated with their generation in association with respiratory cytochromes like complex III and is associated with the generation of $\mathrm{H}_{2} \mathrm{O}_{2}$ within mitochondrial cristae, whereas, complex I and II contribute $\mathrm{H}_{2} \mathrm{O}_{2}$ within the mitochondrial matrix [106]. The $\mathrm{H}_{2} \mathrm{O}_{2}$ removal from cells is mainly carried out by natural antioxidant enzymes like dismutation of catalases, peroxidases like glutathione peroxidases (GPxs), and peroxiredoxins in the form of $\mathrm{H}_{2} \mathrm{O}$ and $\mathrm{O}_{2}$ (Figure 3) $[55,107,108]$. GPxs are a family of selenoenzymes homologous to selenocysteine, containing mammalian GPx-1, and have a high degree of affinity for $\mathrm{H}_{2} \mathrm{O}_{2}$ in humans. GPx-1 is one of the most expressed and abundant members of the GPx family of enzymes that include an epithelial-specific enzyme that is highly expressed in the intestine (GPx-2); a secreted subtype (GPx-3); and GPx-4, which is widely expressed and differs in its substrate specificity compared to the other family members. Accordingly, GPx-1 is a key selenoenzyme, an enzyme involved in alleviating the detrimental effects of $\mathrm{H}_{2} \mathrm{O}_{2}[109,110]$. It is present in all cells; found in cytosolic, mitochondrial, and, in some cells, in peroxisomal compartments, GPx-1 can also reduce lipid hydroperoxides and other soluble hydroperoxides. GPx-4 [111] and GPx-7 [112] are also known to scavenge $\mathrm{H}_{2} \mathrm{O}_{2}$ in humans but are not globally expressed compared to GPx-1 [109]. 


\section{A)}

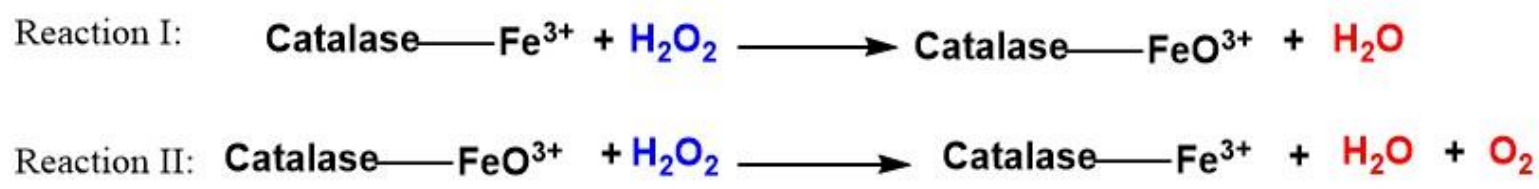

In Sum: $\quad 2 \mathrm{H}_{2} \mathrm{O}_{2} \longrightarrow 2 \mathrm{H}_{2} \mathrm{O}+\mathrm{O}_{2}$

B)

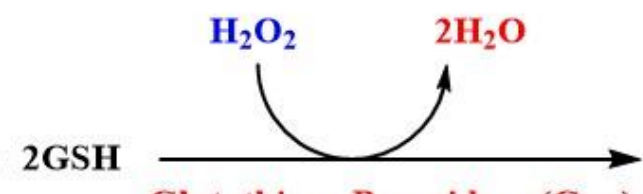

\section{GSSH Oxidized Glutathione}

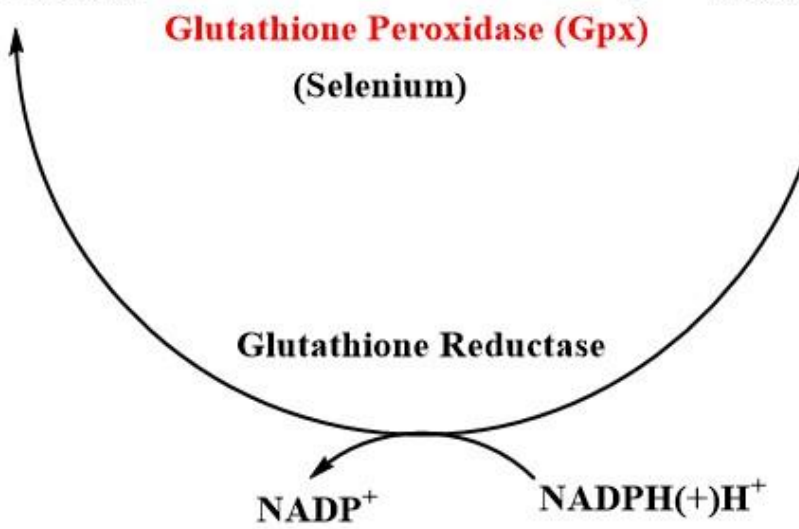

C)

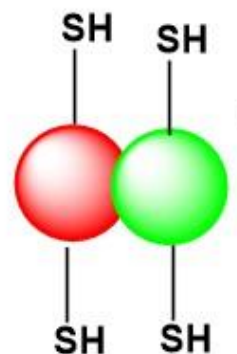

Cysteine Sulphenic Acid Formation

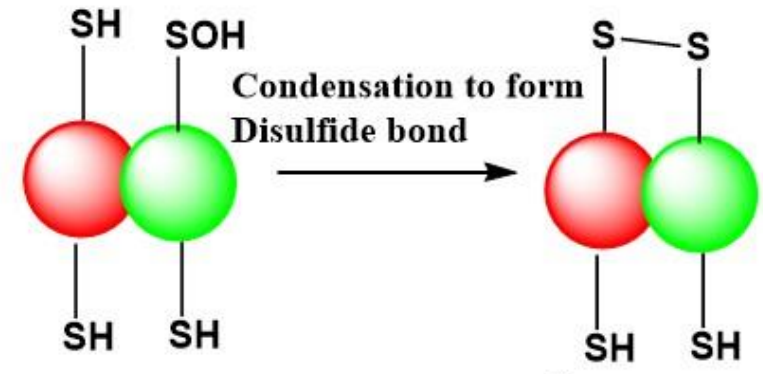

Cysteine Peroxiredoxin

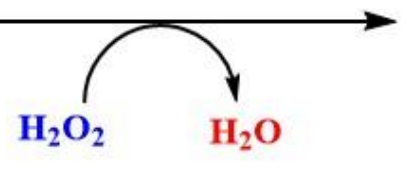

$\checkmark$

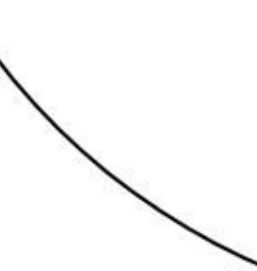

Reduction by Thioredoxin System

Figure 3. Antioxidant actions of various natural defense systems present in our body to scavenge hydrogen peroxide $\left(\mathrm{H}_{2} \mathrm{O}_{2}\right)$. (A) Catalase system. (B) Glutathione peroxidase (GPxs) system. (C) Peroxiredoxin system. Abbreviations: $(\mathrm{SH})$, thiol; (-SOH), sulphenic acid; (-S-S-), disulfide bond; NADP+, nicotinamide adenine dinucleotide phosphate; $\mathrm{NADPH}(+) \mathrm{H}+$, reduced nicotinamide adenine dinucleotide phosphate; GSH, reduced glutathione; GSSH, oxidized glutathione. 


\subsection{Generation of Highly Unstable and Reactive Free Radical Species, the $\mathrm{HO}$ from $\mathrm{H}_{2} \mathrm{O}_{2}$}

$\mathrm{Fe}$ is a component of various metalloproteins in living systems and is involved in several critical biochemical processes like oxygen transport through hemoglobin, electron transport during respiration in mitochondria, synthesis, and repair of nucleic acids, metabolism of xenobiotics, essential for oxidation-reduction catalysis and bioenergetics though heme of cytochrome enzymes [113]. Three major classes of Fe-containing proteins facilitate oxygen-based chemistry in living cells: iron-sulfur cluster-containing proteins; heme-containing proteins; and iron-containing enzymes that are devoid of iron-sulfur clusters or heme. The redox ability of Fe makes it an indispensable metal of life, making it a key element in numerous biochemical processes of life [114]. However, the ability to take part in (oxidation, reduction cycle) renders Fe to act as a catalyst in a free state to generate toxic free radicals in oxygen-consuming organisms. For this reason, the circulating $\mathrm{Fe}$ is protected in a tightly bound state in form of Fe carrier transferrin, which keeps $\mathrm{Fe}$ in its inactive redox state. On the other hand, physiological cells also have some free Fe called labile $\mathrm{Fe}$, which acts to generate free radical $\mathrm{H}_{2} \mathrm{O}_{2}$, for redox signaling. However, any alteration in the normal pool of either bound or labile Fe in a state of redox disbalance will give stimulus to start Fenton chemistry to form one of the most toxic radical $\mathrm{HO}^{\bullet}$. Over the last few decades, the role of Fe in neurodegenerative diseases has grabbed everybody's attention $[115,116]$. The requirement of Fe in the brain is high because of the high demand for energy $[117,118]$. Fe is an important component for the synthesis of neurotransmitters and myelin sheath of the neuron [119]. Fe toxicity due to Fe deposition and Fe-related oxidative damage is implicated in various neuropathology such as AD, PD, and ALS [120]. A large number of evidence suggests that $\mathrm{Fe}$ is involved in the onset and progression of ALS. Fe load was evident in the spinal cord of ALS patients [121], the motor cortex of ALS patients [122], gray matter from the frontal cortex of ALS patients [123], in the serum of ALS patients [124], and the CSF of ALS patients [125]. Recent evidence has shown that oxidative burst due to Fenton chemistry is implicated in the pathology of ALS [116,126-128].

Fe and $\mathrm{H}_{2} \mathrm{O}_{2}$ are involved in creating oxidizing environments inside living systems, causing the oxidation of biomolecules and hence cell damage. Being a transition metal, it has the capability to undergo oxidation and reduction inside living systems. Fe can react catalytically with $\mathrm{H}_{2} \mathrm{O}_{2}$ to form highly reactive and toxic species. Higher concentrations of $\mathrm{H}_{2} \mathrm{O}_{2}$ in the range of $>100 \mathrm{nM}$ cause disruptive redox signaling, causing oxidative distress and therefore, the oxidation of biomolecules. A higher concentration of $\mathrm{H}_{2} \mathrm{O}_{2}$ undergoes Fenton's reaction, which is a kind of disproportionation redox chemical reaction in the presence of ferrous ion $\left(\mathrm{Fe}^{+2}\right)$ or $\mathrm{Cu}$. The toxicity of $\mathrm{H}_{2} \mathrm{O}_{2}$ is mainly due to the generation of an $\mathrm{OH}^{\bullet}$ via the Fenton reaction in the presence of transition metal ion $\mathrm{Fe}$ or $\mathrm{Cu}$ (Figure 4), or via Haber-Weiss reaction in the presence of $\mathrm{O}_{2}{ }^{\bullet-}$ [129].

The $\mathrm{OH}^{\bullet}$ is the most powerful oxidant among the ROS, with a potential of $\mathrm{E}^{0}\left(\mathrm{HO} \bullet / \mathrm{H}_{2} \mathrm{O}\right)=2.34 \mathrm{~V}$. At very low $\mathrm{pH}, \mathrm{HO}^{\bullet}$ converts into its conjugate base $\mathrm{O}^{\bullet-}\left(\mathrm{pKa}\left(\mathrm{HO}^{\bullet} ; \mathrm{O}^{\bullet-}\right)=11.9\right)$, the oxide radical, which is less reactive but not relevant at physiological $\mathrm{pH}$ [36]. The $\mathrm{HO}^{\bullet}$ radical is electrophilic in nature and has a strong affinity towards aromatic and sulfur-containing biomolecules. There are three modes of action for the $\mathrm{HO}^{\bullet}$ radical: electron abstraction, hydrogen abstraction, and double bond addition. The addition of $\mathrm{HO}^{\bullet}$ radical causes oxidation of biomolecules, like 8-oxoguanine from guanine [130] and 2-oxo-histidine from histidine [131]. Whereas oxidation of sulfur-containing amino acid Met forms Met sulphoxide and sulphone [132]. Electron abstraction is also observed with inorganic substrates like $\left(\mathrm{Fe}^{+2}\right)$ [133]. The $\mathrm{H}^{-}$abstraction mechanism is involved in reactions with various biomolecules, such as polyunsaturated fatty acids like linoleate and arachidonate [134], also from $(\mathrm{SH})$ or hydroxyl $(\mathrm{OH})$ functional groups from different proteins and peptides [135]. This $\mathrm{HO}^{\bullet}$ initiates lipid peroxidation to form lipid peroxides ultimately leading to the formation of malonaldehyde or 4-Hydroxy-2-Nonenal (4-HNE), causing alteration in gene expression and promoting cell death [136]. 


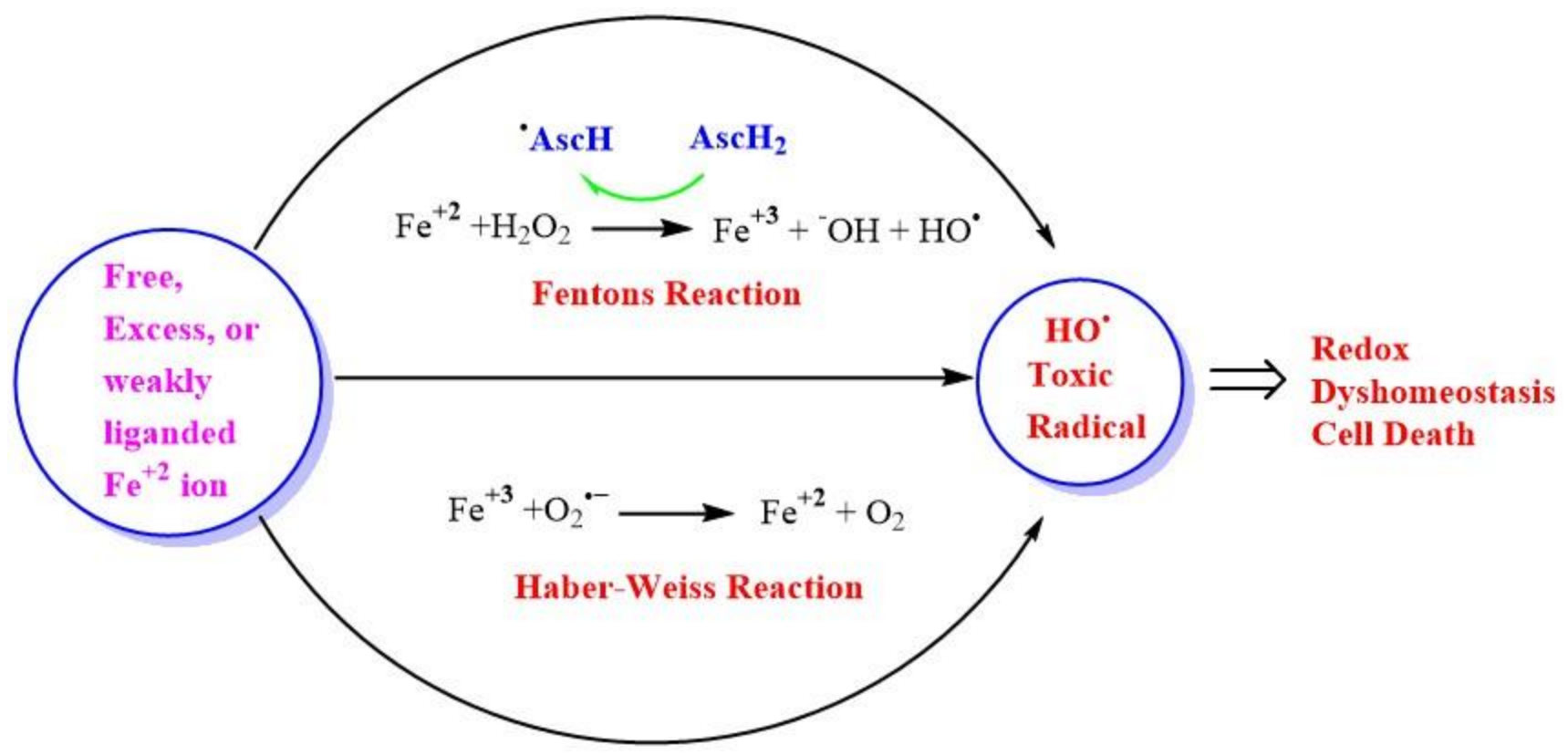

Figure 4. Generation of highly reactive oxidant hydroxyl radicals $(\mathrm{HO} \bullet)$. Free ferrous ion $\left(\mathrm{Fe}^{+2}\right)$ initiates Fenton reaction with hydrogen peroxide $\left(\mathrm{H}_{2} \mathrm{O}_{2}\right)$, leading to the generation of a highly reactive hydroxyl free radical $\left(\mathrm{HO}^{\bullet}\right)$. Ascorbic acid $(\mathrm{AscH})$ also, take part in recycling the ferric ion $\left(\mathrm{Fe}^{+3}\right)$, through the generation of $\left(\mathrm{Fe}^{+2}\right)$ and ascorbyl radical $\left(\mathrm{AscH} \mathrm{H}^{\bullet}\right)$. Superoxide radical anion $\left(\mathrm{O}_{2}{ }^{\bullet-}\right)$ can also react with $\left(\mathrm{Fe}^{+3}\right)$ in the Haber-Weiss reaction leading to the production of $\left(\mathrm{Fe}^{+2}\right)^{\prime}$ which then again starts redox cycling to generate $\mathrm{HO}^{\bullet}$. The $\mathrm{HO}^{\bullet}$ leads to oxidative stress-induced lipid peroxidation, mitochondrial dysfunction, and an increase in intracellular free-calcium concentration, and finally causing redox imbalance within the cell and ultimately leading to cell death.

$\mathrm{H}_{2} \mathrm{O}_{2}$ can also be converted into a $\mathrm{HO}^{\bullet}$ in the presence of a superoxide radical anion ion called Heber-Weiss reaction [36,137]. Intriguingly, ascorbic acid, which is one of the antioxidants present in the lining of lungs and prevents the harmful effects of pollution, can also generate cytotoxic $\mathrm{OH}^{\bullet}$ when it is oxidized in the presence of hydrogen peroxide and transition metal catalyst like $\mathrm{Fe}$ and $\mathrm{Cu}$ in vitro [71]. This led to the development of acellular assays to measure particle-bound ROS and aerosol oxidative potential (OP) of the particulate matter present in air pollution [138]. Furthermore, it is important to note that, ascorbic acid acts as a pro-oxidant and recycles the ferric ion $\left(\mathrm{Fe}^{+3}\right)$ to $\left(\mathrm{Fe}^{+2}\right)$, hence, facilitating and enhancing the generation of ROS, through successive Fenton cycles [139].

\section{Amyotrophic Lateral Sclerosis}

ALS is a motor neurodegenerative disease (MNDs) that is due to the gradual deterioration of voluntary muscle function due to progressive loss of the lower and upper motor neurons. It is a progressive paralytic disorder, which causes degeneration of motor neurons in the brain and spinal cord [140]. The disease was first described in 1869 by French neurologist Jean-Martin Charcot. Therefore, ALS is also known as Charcot disease in honor of the first person who describes it [140]. The disease become well known in the United States when famous baseball player Lou Gehrig was diagnosed with the disease and died at the age of 37 years [141]. Early symptoms of ALS generally include muscle weakness. Slowly all voluntary muscles are wasted throughout the body, and eventually, the brain loses its ability to control voluntary body movements. Individuals suffering from ALS lose their strength, ability to speak, eat, move, and even breathe although intellect is largely unaffected [141]. Eventually, people with ALS die due to respiratory failure, usually within 3-5 years after first diagnosis $[140,142]$. ALS is the most common MND and it accounts for $80-90 \%$ of all MND cases [143]. There is an increasing number of patients diagnosed with ALS globally. Recent reports have shown that the incidence of ALS is between 0.6 and 
3.8 per 100,000 persons-years [144-147]. Recent studies have reported the prevalence of ALS is between 4.1 and 8.4 per 100,000 persons [147-151]. These two parameters show that the burden of the disease is increasing globally [151]. ALS is characterized by two forms. The most common form of this disease is sALS (90-95\%), the etiology of which is still unknown and there is no obvious genetic component associated. The remaining (5-10\%) of the cases are fALS, which is due to the association of genetic dominant inheritance factor [141].

ALS is a highly complex, incurable, idiopathic illness, and life-threatening disease. It is thought to be a multifactorial disease, with no one cause being well established to date [152]. In 1993, mutations in the SOD1 gene encoding Cu, Zn SOD1 protein were reported as the first genetic link to fALS [7]. Presently, more than 180 mutations are reported in the SOD1 gene [153]. The most common cause of ALS is a mutation of the SOD1 gene encoding the antioxidant enzyme SOD1 [154]. Because of the high incidence of SOD1 mutations, which accounts for $20-25 \%$ of fALS cases, which represents 1 to $2 \%$ of all ALS cases, SOD1 is regarded as the most comprehensively studied gene and is one of the prime targets to find therapeutic options for treatment of ALS [155]. fALS which is a mutant SOD1 (mSOD1) induced form of ALS and is almost identical to the late-onset, classical form of ALS called sALS. Both of these forms of ALS are clinically indistinguishable and both share common clinical features, such as the presence of inclusion bodies, motor neuron death, and dysfunction, glial reactivity [156]. The only difference between SOD1-fALS and classic sALS is that individuals with sALS have an average age of onset of 56 years, compared with 46 years for fALS with SOD1 mutations [157]. The variability in the clinical course of disease presentation among fALS patients is seen due to the presence of various genetic mutations in the SOD1 gene. Which is found to be similar in the case of sALS [158]. Research has shown that fALS are mainly due to the mutations of four genes: The chromosome 9 open reading frame 72 (C9ORF72) [159], SOD1 [7], RNA-binding protein fused in the sarcoma (FUS) [160], and TAR DNA binding protein 43 (TDP-43) [161]. A large body of evidence suggested that SOD1 plays an indispensable role in the pathogenicity of both forms of ALS and is a common protein, which is pathologically associated with both forms. In the case of fALS, a mutation in the SOD1 gene called mSOD1 causes misfolding of SOD1 protein. On the other hand, in the case of sALS, non-genetic post-translational modifications (PTMs), such as loss of metal, disruption of quaternary structure, and oxidation of wildtype SOD1 protein by free radicals could cause misfolding of SOD1 protein $[11,158]$. These aberrant conformation cause wtSOD1 in case of sALS to acquire the same toxic function that are observed for fALS-associated mSOD1variants [88,154,155,158,162]. Moreover, a large number of studies have shown that the misfolding of SOD1 protein is the major culprit in causing the loss of around $70 \%$ of spinal cord motor neurons [163-168]. In addition, a breakthrough was the discovery of SOD1 transgenic mutant mice like (SOD1 ${ }^{\mathrm{G} 93 \mathrm{~A}} \mathrm{Tg}$ ), $\left(\mathrm{SOD} 1^{\mathrm{G} 37 \mathrm{R}} \mathrm{Tg}\right)$ or $\left(\mathrm{SOD} 1^{\mathrm{G} 85 \mathrm{R}} \mathrm{Tg}\right)$. These $\mathrm{mSOD} 1 \mathrm{mice}$ developed a motor neuron disease with many pathological changes reminiscent of human ALS [169] and further increased our understanding of the association of the SOD1 gene in ALS [170].

\section{Cu, Zn Superoxide Dismutase Enzyme}

SOD1 is a highly conserved member of the human SOD family of proteins, which also includes SOD2 and SOD3. All the three proteins are distinct from each other and act as antioxidants by scavenging $\mathrm{O}_{2}^{\bullet-}$ to $\mathrm{H}_{2} \mathrm{O}_{2}$ [171]. SOD1 is mainly found in the cytosol and inner membrane of the mitochondria [172] and comprises $\sim 1 \%$ of total protein in the cell [173]. SOD2 is found mainly in the mitochondrion matrix. Contrary to SOD1 and SOD2, SOD3 is mostly located outside the cell in the extracellular matrix. Another major difference is that SOD1 is a homodimer while SOD2 and SOD3 are homotetrameric proteins; SOD1 and SOD3 catalyze the dismutation of $\mathrm{O} 2^{\bullet-}$ through dismutation of $\mathrm{Cu}^{+2}$, whereas SOD2 utilizes manganese $(\mathrm{Mn})$ as a redox-active transition metal for dismutation. SOD1 isoform of the protein is mainly involved in the pathology of ALS [158]. 
The Eukaryotic SOD1 is a stable homodimer [174]. The dimer is held together principally by hydrophobic interactions. Each SOD1 monomer contains two transition metal ions, one $\mathrm{Cu}$ and one Zinc $(\mathrm{Zn})$, both of which play an important catalytic and structural role in the enzyme [174].

SOD 1 is a $32 \mathrm{kDa}$ homodimeric SOD1 protein and adopts an eight-stranded Greek key beta-barrel structural motif. Homodimerization of SOD1 protein reduces the solventaccessible area, making it more stable. The fully metallated form of SOD1 protein melts at 85-95 C [175]. Two functional loops are present in SOD1: the electrostatic loop that guides superoxide into the redox-active site where $\left(\mathrm{Cu}^{+2}\right)$ and the $\mathrm{Zn}$-binding loop is located [11,174]. The catalytic $\mathrm{Cu}$ is coordinated to SOD1 by four histidines $(46,48,63$ and 120) residues in oxidized form $\mathrm{Cu}^{+2}$ and three histidine residues $(46,48$ and 120) in its reduced form $\left(\mathrm{Cu}^{+1}\right)[176,177]$. The structurally vital $\mathrm{Zn}$ ion acts as a monodentate ligand and is thought to play an important role in maintaining the structure of SOD1 and acts as a positive charge ion sink. The $\mathrm{Zn}$ ion is coordinated by three histidines $(63,71$ and 80$)$ and one aspartate (83). Coordination of $\mathrm{Cu}$ to SOD1 is required for its catalytic dismutation activity to scavenge $\mathrm{O}_{2}{ }^{\bullet-}$ [172] through a ping pong mechanism (Figure 5) [11]. Other PTMs like coordination of $\mathrm{Zn}^{2+}$, modulating the folding free energy of SOD1 [178], and oxidation of a (-S-S-), are important to form the mature structurally stable SOD1 protein. A distinctive functional feature of SOD1 is the presence of an intra subunit (-S-S-) between $\mathrm{Cys}^{57}$ and $\mathrm{Cys}^{146}\left(\mathrm{C}^{57}-\mathrm{C}^{146}\right)$, which is atypical for proteins that reside in the highly reducing environment of the cytosol [174].

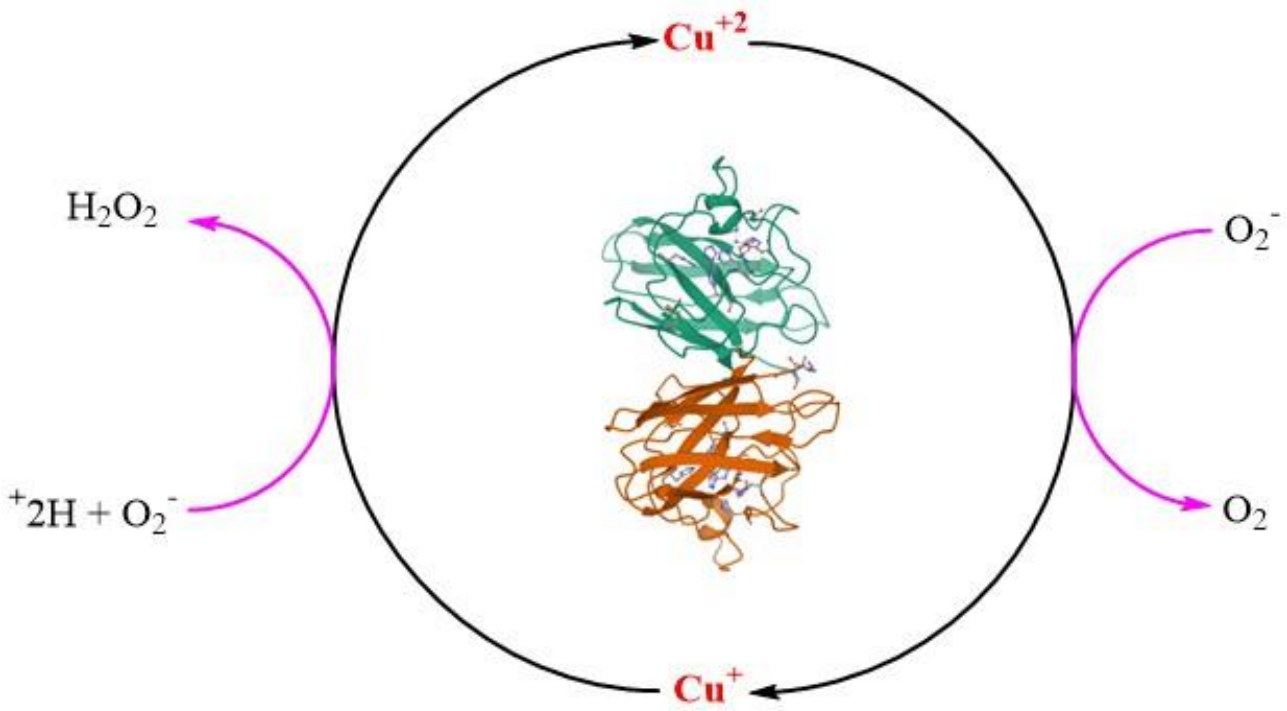

Figure 5. Structure of superoxide dismutase1 (SOD1) dimer (pdb code: 1SPD). The catalytic role of copper $(\mathrm{Cu})$ in the dismutation reaction of superoxide radical anion $\left(\mathrm{O}_{2}{ }^{\bullet-}\right)$.

\section{Role of $\mathrm{H}_{2} \mathrm{O}_{2}$ in Misfolding of $\mathrm{Cu}, \mathrm{Zn}$ SOD1}

Even with the above literature findings, we could say that ALS is highly complicated and still the molecular mechanism and its etiology are unknown and not resolved. However, a large body of evidence has shown that SOD1 is the major protein that serves as a hallmark in ALS disease progression. Current research and findings have largely demonstrated two leading hypotheses which are thought to play an indispensable role in ALS disease. Firstly, increased oxidative stress causes SOD1 toxicity, and secondly, aberrant misfolding of SOD1 protein structure. These two factors are interrelated to each other [12]. Before going into the hypothesis of SOD1 misfolding herein, we should discuss what is misfolding of a protein. A protein is said to be folded if it is present in its regular conformation or structure, including the elements of secondary structure [11]. The native state of a protein is often folded and forms the operative structure of a protein. A protein is said to be unfolded if it does not possess a regular structure and is highly soluble [179]. 
SOD1 maturation or SOD1 folding requires four post-translational maturation steps in addition to N-terminal acetylation. Firstly, $\mathrm{Cu}$ insertion, secondly, Zn insertion, thirdly dimerization of monomer units, and lastly, (-S-S-) formation between monomer units. These PTMs provide SOD1 structure, function, and stability. Therefore, any alteration in these PTMs causes accumulation of immature SOD1, causing improper folding or unfolding of SOD1 [11]. It is evident that the maturation of SOD1 to its functional form itself is a universal process that requires oxidation, however, the misfolding of SOD1 that acquires toxic function is due to the result of an oxidative environment of the motor neuron. Several reports have shown that misfolding and toxicity are caused by oxidative free radicals [12,154,180,181]. Therefore, according to our current understanding, herein we aim to contemplate that the most important free radical which is responsible for the misfolding and toxicity of SOD1, is $\mathrm{H}_{2} \mathrm{O}_{2}$, and thereby plays a critical role in the pathophysiology of ALS.

Initial evidence to support our conjecture was given by Liu and co-workers (2020) [115], they have for the first time, using unique microdialysis and microcannula sampling techniques in transgenic mutant mice, demonstrated that the levels of $\mathrm{H}_{2} \mathrm{O}_{2}$ and $\mathrm{HO}^{\bullet}$ are significantly higher than the level of $\mathrm{O}_{2}{ }^{\bullet-}$ in ALS transgenic mutant mice compared to control. Showing the in vivo evidence that the "mSOD1catalyses" the formation of $\mathrm{OH}^{\bullet}$ radical through the following steps. In addition, these studies suggested that $\mathrm{H}_{2} \mathrm{O}_{2}$ formed by overexpression of humanSOD1 (hSOD1) is efficiently destroyed, whereas more of $\mathrm{H}_{2} \mathrm{O}_{2}$ produced by the mSOD1 escapes into the tissue where it may produce damaging $\mathrm{HO}^{\bullet}$, thereby causing the oxidation of protein, DNA, and membrane phospholipids causing motor degeneration in ALS. Moreover, this study also proves the theory of acquiring a new function of mSOD1, blocking $\mathrm{H}_{2} \mathrm{O}_{2}$ conversion to $\mathrm{H}_{2} \mathrm{O}$, thereby allowing more $\mathrm{HO}^{\bullet}$ formation from $\mathrm{H}_{2} \mathrm{O}_{2}$ [115].

The gain of function theory for mSOD1 in ALS pathogenesis was supported by Yim and co-workers (1990) [23]. They demonstrated the enhancement of free radical formation due to a decrease in the Michaelis constant $(\mathrm{Km})$ for $\mathrm{H}_{2} \mathrm{O}_{2}$ as measured by the spin trapping method in the SOD1 ${ }^{\mathrm{G} 93 \mathrm{~A}}$ ALS model. According to their studies, the free radical generating function of mutant G93A is enhanced compared to the wild type of enzyme, particularly at lower concentrations of $\mathrm{H}_{2} \mathrm{O}_{2}$. This was found to be due to the decrease in the value of $\mathrm{Km}$ for $\mathrm{H}_{2} \mathrm{O}_{2}$ for $\mathrm{G} 93 \mathrm{~A}$ with the same turnover number of the enzyme (Kcat) value for both mSOD1 and wSOD1, thus the ALS symptom observed in the G93A ALS model is due to the gain of function, i.e., an increase in the function to generate free radicals [23]. Thus, this study supported the fact that $\mathrm{H}_{2} \mathrm{O}_{2}$ acts as a substrate to produce an elevated amount of toxic free radicals $\mathrm{HO}^{\bullet}$, which is due to the low $\mathrm{Km}$ value of $\mathrm{H}_{2} \mathrm{O}_{2}$ for mSOD1 compared to wSOD1. This enhancement of free radical generating function is thought to inactivate the enzyme, through disturbance in the PTMs process to form mature SOD1. Jewett and his team, observed the oxidation of matured SOD1 with $\mathrm{H}_{2} \mathrm{O}_{2}$ causes a sequence of events, the first being the formation of 2-oxo-histidine, $\mathrm{Cu}$ loss and thus causing inactivation of the catalytic property of SOD1 [182]. This study again suggested the role of $\mathrm{H}_{2} \mathrm{O}_{2}$ as a substrate in the inactivation of SOD1.

Further, Sampson and co-workers (2001) [183], studied the effects of $\mathrm{H}_{2} \mathrm{O}_{2}$ on $\mathrm{Zn}$ deficient SOD (Cu, E SOD) and $\mathrm{Cu}, \mathrm{Zn}$ SOD using bovine SOD invitro. They demonstrated firstly, that $\mathrm{H}_{2} \mathrm{O}_{2}$ exposure to $\mathrm{Cu}, \mathrm{E}$ SOD inactivated zinc-binding activity six times faster than dismutase activity. Although, the rate of loss of dismutase activity is the same for both the SOD. Secondly, they detected through UV circular dichroism that $\mathrm{H}_{2} \mathrm{O}_{2}$ instigate elusive changes in the tertiary structure of $\mathrm{Cu}, \mathrm{E} \mathrm{SOD}$, but not the secondary structure. Finally, they showed that $\mathrm{H}_{2} \mathrm{O}_{2}$ in a lower concentration of $1 \mathrm{mM}$ amplifies the toxicity of $\mathrm{Zn}$ deficient $\mathrm{Cu}$, E SOD to motor neurons in ALS manifesting the Zn loss from SOD [183]. The aberrant misfolding of mSOD1 adversely affects the binding of $\mathrm{Zn}$ in the $\mathrm{Zn}$ binding sites of mSOD1, thereby, decreasing the affinity of Zn inmSOD1 [184-186]. The gain of the toxic function of SOD1 is due to the loss of $\mathrm{Zn}$ metal. Two major factors are involved in the loss of $\mathrm{Zn}$ from SOD1 in the case of ALS pathology. The first is the presence of high 
neurofilaments (NFs), and the second is the presence of a pathological concentration of $\mathrm{H}_{2} \mathrm{O}_{2}$. NFs are intermediate filaments that comprise the neuronal cytoskeleton and are abundant in the axons. Recent evidence has shown the presence of elevated NFs light chain and phosphorylated NFs heavy chain levels in the CSF and serum ALS patients, speculating the extensive damage of motor neurons and axons [187-189]. Similar, to SOD1, NFs are found abundantly in motor neurons and are known to bind to metals [190]. In case of elevated levels of NFs in ALS, NFs could act as a sink for Zn and could remove Zn from both wSOD1 and mSOD1, making SOD1 deficient of Zn, thereby, enhance the catalysis of tyrosine nitration by $\mathrm{ONOO}^{-}$. Because zinc shares a common histidine ligand with $\mathrm{Cu}$, Zn deficiency may also alter the redox properties of copper [191,192]. Whereas the second factor is the neurotoxic levels of $\mathrm{H}_{2} \mathrm{O}_{2}$ that modifies the (SH) status of both wSOD1 and mSOD1 to acquire the toxic gain of function and thus, causing the elimination of $\mathrm{Zn}$. In the case of increased ROS in motor neurons, the pathological concentration of $\mathrm{H}_{2} \mathrm{O}_{2}$ makes the process of Zn recovery irreversible and thus causing structural defects in SOD1 structure even in the presence of small antioxidants inducing misfolding and thus toxicity to motor neurons [183]. The above findings supported the fact that the pool of $\mathrm{Zn}$ in SOD1 is an important factor in the neuropathology of ALS.

The above findings were additionally supported by Rakhit and co-workers (2002) [12], with the help of dynamic light scattering and analytical ultracentrifugation, they found that the most aggregation-prone species is Zn deficient SOD1 and is amenable to form toxic aggregates. As mSOD1 is less stable than wSOD1, oxidative stress through the generation of $\mathrm{H}_{2} \mathrm{O}_{2}$ as substrate causes the formation of an irreversible $\mathrm{Zn}$ deficient and consequently a monomeric intermediate state of the protein. These two intermediate acts as a transition state intermediate before aggregation [12]. Thus, this study proved that oxidative stressinduced Zn deficient SOD1 is vulnerable to aggregation and thus misfolding.

Further, studies have identified that the disruption of $\mathrm{Cu}$ homeostasis due to oxidative stress is responsible for toxic SOD1 aggregate formation [19,193]. Also, Cu deficiency was found in the spinal cord of transgenic mutant mice having poor locomotor function, supporting the role of $\mathrm{Cu}$ in maintaining the integrity and folding of the SOD1 structure [194,195]. Evidence from the literature has shown that pathological $\mathrm{H}_{2} \mathrm{O}_{2}$ attacks the $\mathrm{Cu}$ binding histidine [196,197], eventually leading to Cu loss and hence, SOD1 deactivation [182].

The functional role of metals in maintaining the dynamics of SOD1 is well established by the fact that SOD1 monomer, which is metal deficient apoSOD1 species, are vulnerable to change in dynamics leading to misfolding and hence act as a precursor for aggregation. [11,12,198-200]. Therefore, both the metals are vital in maintaining the homeostasis and redox properties of SOD1 protein and loss of metals called demetallation due to oxidative stress caused by pathological $\mathrm{H}_{2} \mathrm{O}_{2}$ from holoSOD1 causing its misfolding and hence disease progression of ALS.

The peroxidase hypothesis describes that mSOD1 could act as a peroxidase and has the ability to generate $\mathrm{HO}^{\bullet}$ radical from $\mathrm{H}_{2} \mathrm{O}_{2}$, thus creating an oxidative environment in motor neurons creating toxic aggregates [201]. Other studies showed that the biologically ubiquitous bicarbonate buffer-dependent reaction initiated by $\mathrm{H}_{2} \mathrm{O}_{2}$ generated by peroxidase activity of hSOD1 causes the formation of oxidation products of the hSOD1-Trp32 residue, particularly the covalent dimer, in triggering the non-amyloid aggregation of hSOD1 [202] This study was well supported by other reports, which suggested that the overexpression of hSOD1WT in mice causes ALS [203], and, the presence of over-oxidized/carbonylated hSOD1WT in sporadic ALS patients [204].

Moreover, the importance of (SH) status in the central nervous system (CNS) also determines the cytotoxic level of $\mathrm{H}_{2} \mathrm{O}_{2}$. During the cellular process, $(\mathrm{SH})$ oxidation mainly of Cys and glutathione act as a hot spot in CNS, to produce neurotoxic $\mathrm{H}_{2} \mathrm{O}_{2}$, thereby making neurons vulnerable to $\mathrm{HO}^{\bullet}$ radicals [205]. A large body of evidence has shown that redox modification of a Cys amino acid, mainly Cys ${ }^{111}$ in SOD1, by $\mathrm{H}_{2} \mathrm{O}_{2}$ is mainly implicated in the pathology of ALS [206-209]. Cys ${ }^{111}$ is a primary target for oxidative modification and plays a crucial role in oxidative damage to hSOD1, including mSOD1 [206] (Figure 6). 
Bosco and colleagues (2010) [210], employed Fourier transform mass spectrometry (FT-MS) to confirm the oxidation of wSOD1 with the exposure of $\mathrm{H}_{2} \mathrm{O}_{2}$. They found that there was an increase of $48 \mathrm{Da}$ for the predominant species in the spectrum of oxidized wSOD1, compared to unmodified wSOD1. Further, they confirmed with the help of electron capture dissociation (ECD) technique, that the $(\mathrm{SH})$ group in $\mathrm{Cys}^{111}$, encoded in exon 4 to be the most vulnerable amino acid, which is found to be irreversibly oxidized to sulphonic acid, through the addition of three atoms of oxygen. Therefore, $\mathrm{Cys}^{111}$ acts as a hot spot for oxidative modification by $\mathrm{H}_{2} \mathrm{O}_{2}$ [210]. Supporting the role of $\mathrm{H}_{2} \mathrm{O}_{2}$ in altering the spectroscopic and biophysical properties of Cys ${ }^{111}$ in SOD1 [207].

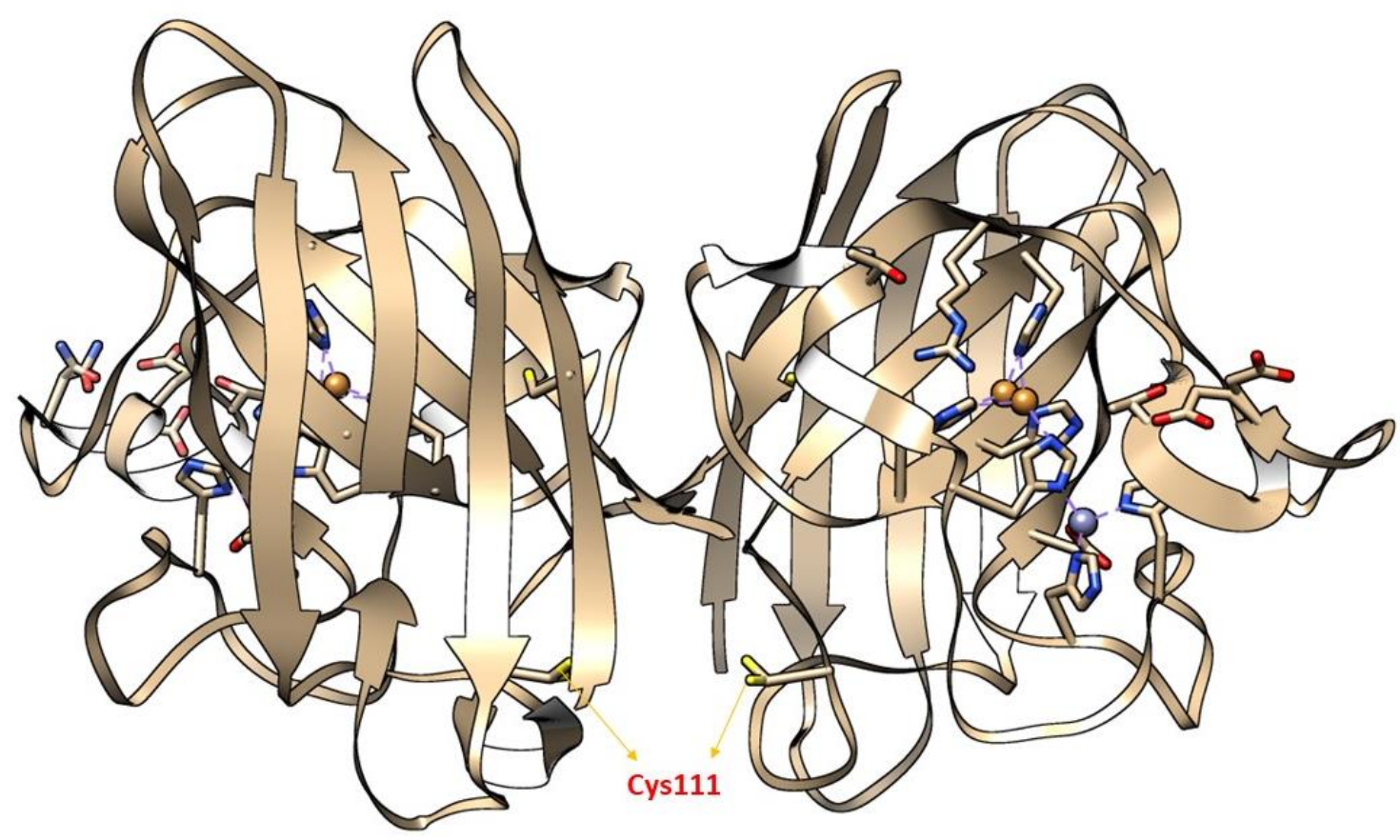

Figure 6. The X-ray crystallographic structure of wild-type SOD1 (wSOD1) (Pdb\#2C9V) [211] is shown, modeled in Chimera. Cysteine $111\left(\mathrm{Cys}^{111}\right)$ highlighted in the yellow act as a "HOT SPOT" for oxidative modification by hydrogen peroxide $\left(\mathrm{H}_{2} \mathrm{O}_{2}\right)$ and labeled red in the cartoon. The Zinc $(\mathrm{Zn})$ and Copper $(\mathrm{Cu})$ atoms are shown in cyan and orange, respectively [210].

Kong and group (2012) [208], examined the redox state of SOD1 Cys residues in the G37R transgenic animal model under oxidative stress induced by $\mathrm{H}_{2} \mathrm{O}_{2}$. The data suggested that with the progression of disease there is an increase in oxidation of (SH) groups of Cys residues due to an oxidative burden inside the spinal cord motor neurons. This was further proved by an upper shift band in reducing SDS-PAGE, which turned out to be a .ys $^{111}$-peroxidized SOD1 species using MalPEG. MalPEG is an alkylating agent linked with $5 \mathrm{kDa}$ PEG, easily reacts with sulfhydryl groups of Cys residues, and causes a $5 \mathrm{kDa}$ increase in molecular weight per one modification on SDS-PAGE. They demonstrated that oxidation by $\mathrm{H}_{2} \mathrm{O}_{2}$ decreased the MalPEG modification and increased Cys $^{111}$-peroxidation in G37R spinal cord extract. In addition, they also found the formation of different aggregates and multimers during the disease progression which is thought to be due to the formation of abnormal conformational change of SOD1 due to Cys ${ }^{111}$ modification [208]. Thus, the more reactive thiolate of $\mathrm{Cys}^{111}$ is critically involved in the aggregation of the SOD1 process rather than a (-S-S-) causing (-S-S-) independent SOD1 aggregation. Thus, this data supported the role of $\mathrm{H}_{2} \mathrm{O}_{2}$ in the aggregation of SOD1 via the formation of $\left(-S^{-}\right)$in Cys amino acid residue.

Like that of SOD1, TDP-43 is also implicated in the etiology of ALS and this is well supported by many studies [21,212-215]. Cohen (2012) [212] provided evidence that oxidative stress causes inhibition of TDP-43-mediated RNA regulatory functions. Further, they 
found that redox disbalance caused by stressors like pathological concentration of $\mathrm{H}_{2} \mathrm{O}_{2}$ (1-10 mM), causes unusual TDP-43 cross-linking via Cys oxidation and (-S-S-) formation leading to decreased TDP-43 solubility and hence, TDP-43 formation of toxic aggregates, implicated in the pathology of ALS. Moreover, the pathological modification is due to the mislocalization of TDP-43 from the nucleus to the cytoplasm. Further, TDP-43 proteinopathies induced by the pathological concentration of $\mathrm{H}_{2} \mathrm{O}_{2}$ were well demonstrated by Chang (2013) [216]. Lin and group (2020) [217] demonstrated the phenomenon of aberrant oxidative modification of sulfur-containing amino acid Met. Above mentioned studies have shown the role of pathological $\mathrm{H}_{2} \mathrm{O}_{2}$ induced TDP-43 proteinopathy in the pathogenesis of ALS [218].

Cheng $\mathrm{Xu}$ and colleagues (2018) [21], explained how the pathological concentration of $\mathrm{H}_{2} \mathrm{O}_{2}$ regulates the redox biology of $\mathrm{Cys}^{111}$ and regulates the misfolding and toxicity of SOD1 and TDP-43 associated with ALS and suggested that sulfenic acid modification of wSOD1 play a crucial role in the pathogenesis of sporadic ALS. They demonstrated firstly that the increasing concentration of $\mathrm{H}_{2} \mathrm{O}_{2}$ from 20 to $200 \mu \mathrm{M}$ increased the concentration of apo-SOD1 filaments by incredibly increasing maximum thioflavin T (ThT) fluorescence intensity. Secondly, they showed that pathological concentrations of $100 \mu \mathrm{M}$ $\mathrm{H}_{2} \mathrm{O}_{2}$ activate the fibrillization of wild-type human SOD1 in a neuroblastoma cell line (SH-SY5Y). Finally, they detected the sulfenic acid modification of SOD1 via sulfenation of Cys ${ }^{111}$ by pathological concentration of $(0-200 \mu \mathrm{M}) \mathrm{H}_{2} \mathrm{O}_{2}$. Based on the intriguing in vitro experimental data, they continued the experiments to see whether these PTMs could also be observed in cerebrospinal fluid (CSF) of sALS patients. Interestingly, they observed the increased level of sulfenic acid-modified wild-type SOD1 level in cerebrospinal fluid (CSF) of 15 sALS patients compared with 6 age-matched non-ALS control patients. Finally, they hypothesized that pathological concentration of $\mathrm{H}_{2} \mathrm{O}_{2}$ triggers SOD1 fibrillization, by over oxidizing the (SH) of Cys-111. These (-SOH) modified SOD1 is expected to cause cytoplasm mislocalization of human TDP-43 (from the nucleus to the cytosol), forming cytoplasmic TDP-43 oligomers [21]. Thus, change in abnormal (SH) status of Cys ${ }^{111}$ in SOD1 and has been implicated in toxicity of SOD1 and TDP-43 in motor neurons and is illustrated below (Figure 7). These studies once again proved the role of pathological $\mathrm{H}_{2} \mathrm{O}_{2}$ in the pathogenesis of ALS. Further, it also supported the fact that SOD1 aggregates could increase the propensity of TDP-43 aggregation.

Path a (black arrow): The pathological concentration of $\mathrm{H}_{2} \mathrm{O}_{2}$ will cause an abnormal change in thiol status of Cys ${ }^{111}$ (from SOD1-SH to SOD1-SOH) from holoSOD1 called sulfenylation and cause the release of metal-bound ligands like $\mathrm{Cu}$ and $\mathrm{Zn}$ from the active site of holoSOD1, called demetallation. Sulphenylation with demetallation (path a) leads to dissociation of homodimerized holoSOD1 to its monomeric metal deficient SOD1, hence, encouraging the oligomerization and aggregation of SOD1 to neurotoxic misfolded oligomers and aggregates of SOD1 respectively. Both the oligomers and aggregates of SOD1 are neurotoxic to motor neurons and are implicated in the pathogenesis of ALS.

Path b (Red arrow): The pathological concentration of $\mathrm{H}_{2} \mathrm{O}_{2}$ will cause disruptive post-translational modifications (PTMs) via a change in thiol status of Cys ${ }^{111}$ (from SOD1$\mathrm{SH}$ to SOD1-SOH) called sulphenylation of apoSOD1. Sulphenylation thus provokes the oligomerization and aggregation of SOD1 to neurotoxic misfolded oligomers and aggregates of SOD1 respectively. Sulfenic acid-modified SOD1 oligomers could also disrupt the nucleocytoplasmic shuttle (NS-shuttle) between nucleus and cytoplasm, which is responsible for correct translocation of TDP-43 from the cytoplasm to the nucleus, thus incites the mislocalization of TDP-43 from nucleus to cytoplasm and therefore, provoking the oligomerization and aggregation of TDP-43 to neurotoxic misfolded oligomers and aggregates of TDP-43 respectively. Both the oligomers and aggregates of SOD1 and TDP-43 are neurotoxic to motor neurons and are implicated in the pathogenesis of ALS. 


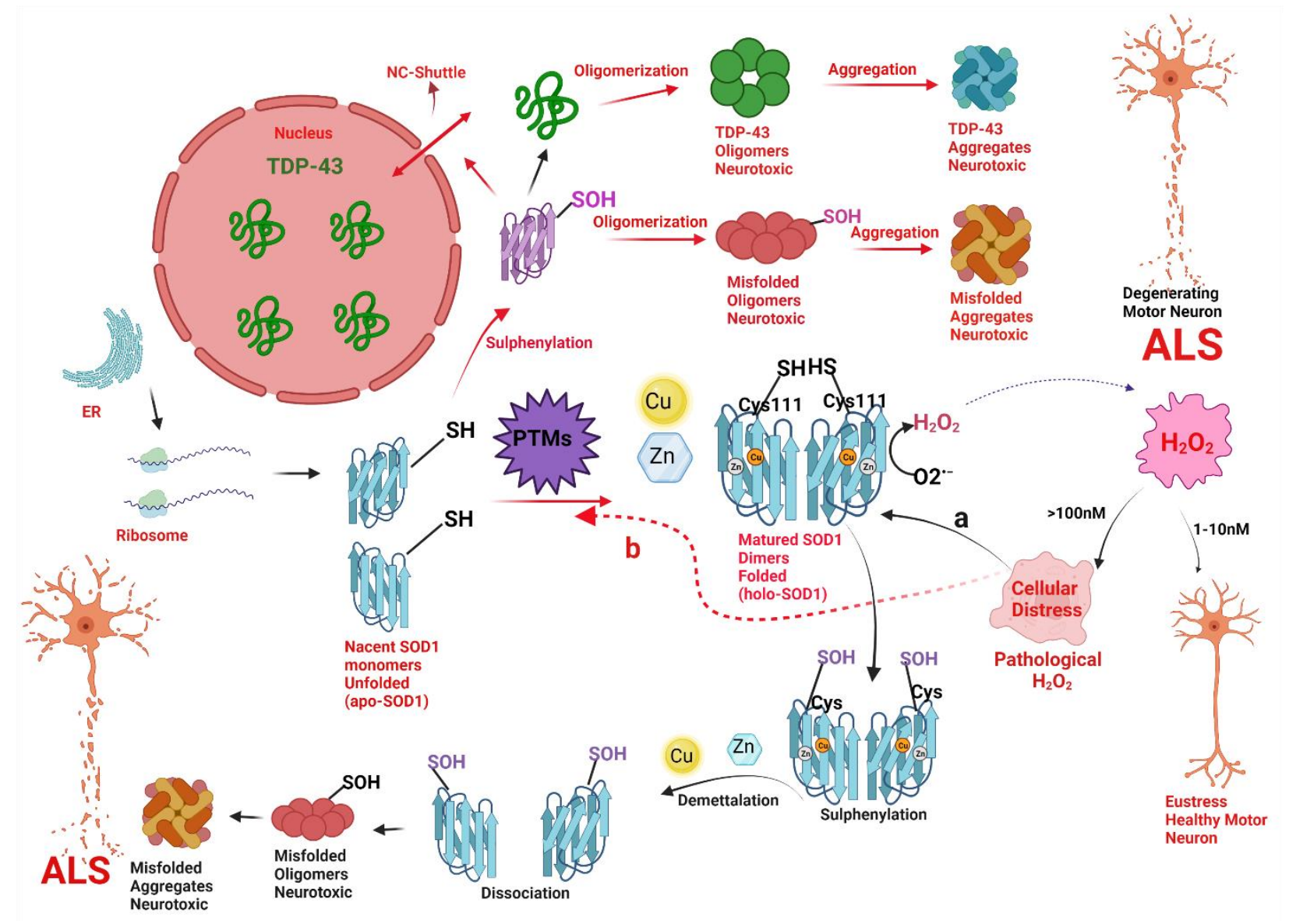

Figure 7. A hypothetical model implicating how pathologic concentrations of hydrogen peroxide $\left(\mathrm{H}_{2} \mathrm{O}_{2}\right)$ prompt the change in conformation and biophysical properties of superoxide dismutase (SOD1) via change in thiol (SH) status of $\mathrm{Cys}^{111}$, and thus instigate SOD1 and TAR DNA-binding protein (TDP-43) toxicity in motor neuronal cells leading to a degeneration of motor neurons in amyotrophic lateral sclerosis (ALS). Nascent SOD1 (unfolded, apoSOD1) released from the ribosomes, undergo post-translational modifications (PTMs) to form homodimerized matured SOD1 (folded, holoSOD1) through the addition of Copper $(\mathrm{Cu})$ and Zinc $(\mathrm{Zn})$ on the correct binding sites of apoSOD1 and formation of disulfide bond (-S-S-). Mature SOD1 catalyzes the dismutation of superoxide radical anion $\left(\mathrm{O}_{2}{ }^{--}\right)$to $\mathrm{H}_{2} \mathrm{O}_{2} \cdot \mathrm{H}_{2} \mathrm{O}_{2}$ acts as a double edge sword molecule and in low concentration i.e., the physiological concentration of $(1-10 \mathrm{nM})$ acts as a signal molecule to create eustress in the cell. However, at higher concentrations i.e., the pathological concentration of (>100 nM) acts to create an oxidative environment for the cells to create cellular distress. The pathological concentration of $\mathrm{H}_{2} \mathrm{O}_{2}$ acts as a reactive oxygen species (ROS) and could cause misfolding of SOD1 via two molecular pathways (Path a and path $\mathbf{b}$ ).

\section{Conclusions}

Oxidative stress due to unstable bio-reactive species is the key factor in the pathophysiology of several neurodegenerative diseases. ALS is one of the highly complex forms of neurodegenerative disease, for which our knowledge about the disease is still scarce and obscure. ALS has complex biology with a large number of variabilities in the molecular targets. However, the discovery of mutations in SOD1 genes encoding SOD1 proteins provided evidence that oxidative stress-induced misfolding of SOD can acquire a toxic gain of function and thereby, act as a critical pathological marker in the pathogenicity of ALS. Literature from the past 20 years has shown that changes in the redox properties of SOD1 cause abnormal conformational changes in the structure of the SOD1 protein leading to a gain of toxic properties, destroying motor neurons in both forms of ALS i.e., sALS and fALS. Therefore, the formation of heterodimers, oligomerization, fibrilization, and 
toxic misfolded inclusions of SOD1 due to oxidative stress is thought to be common in the etiology of ALS. The alteration in the biophysical properties of ubiquitous native SOD1 protein is caused by the dismutation product of the SOD1 catalyzed reaction, called $\mathrm{H}_{2} \mathrm{O}_{2}$.

$\mathrm{H}_{2} \mathrm{O}_{2}$ can display both Jekyll and Hyde behavior as a stable 'diffusible' non-radical oxidant in living cells. The dictation and punctuation of cell signals at various molecular levels depend upon their concentration. Higher concentration of $\mathrm{H}_{2} \mathrm{O}_{2}$, called pathological concentration, acts as a precursor to generating nature's most reactive, harmful, and toxic species called $\mathrm{HO}^{\bullet}$ radical, thus changing the cellular redox thiol status of SOD1 and TDP-43 proteins, and is implicated in the neurodegeneration of motor neurons in ALS. In essence, with our current knowledge, we could say that $\mathrm{H}_{2} \mathrm{O}_{2}$ acts as a modulator of SOD1 redox state mainly via the regulation of PTMs. Hopefully, this insight into the role of $\mathrm{H}_{2} \mathrm{O}_{2}$ in ALS pathology will incite researchers around the globe to think critically about the role of $\mathrm{H}_{2} \mathrm{O}_{2}$ as a decisive denominator in disease progression and may lead to the development of effective therapeutic approaches to stop the devastating course of this disease. To recapitulate, we could say that $\mathrm{H}_{2} \mathrm{O}_{2}$ is the main foci of ROS biology and can act as a principal ROS member in the pathophysiology of ALS.

Author Contributions: N.S. and G.K.T. were involved in the conceptualization and review process of the manuscript. N.S. designed and wrote the manuscript. G.K.T. supervised the writing of the manuscript at every step. N.S. provided the references and prepared all figures in the manuscript. All authors have read and agreed to the published version of the manuscript.

Funding: This research was supported and funded by the group funding from the Research Manitoba 2017 Health Research New Investigator Operating Grant and Natural Sciences and Engineering Research Council of Canada (NSERC) Discovery Grant to G.K.T.

Conflicts of Interest: The authors declare no conflict of interest.

\section{Abbreviations}

RDH: Redox dyshomeostasis; MND: Motor neurodegenerative disease; ALS: Amyotrophic lateral sclerosis; Cu/Zn SOD, SOD1: Copper/zinc superoxide dismutase; mSOD1: Mutant SOD1; ROS: Reactive oxygen species; sALS: Sporadic ALS; fALS: Familial ALS; SOD1: Superoxide dismutase $1 ; \mathrm{H}_{2} \mathrm{O}_{2}$ : Hydrogen peroxide; TDP-43: TAR-DNA binding protein 43; NCI: Neuronal cytoplasmic inclusions; AD: Alzheimer's disease; PD; Parkinson's disease; $\mathrm{HD}$; Huntington's disease; $\left(\mathrm{O}_{2}\right)$ : Molecular oxygen; Fe: Iron; $\mathrm{Cu}$ : Copper; Complex IV: Cytochrome c oxidase; $\left(\mathrm{O}_{2}^{\bullet-}\right)$ : Superoxide radical anion; $\left(\mathrm{HO}^{\bullet}\right)$ : Hydroxyl radical; (Q10): Coenzyme Q; Met: Methionine; Cys: Cysteine; (-SOH): Sulphenic acid; (SH): Sulhydryl or thiol group; (-S-S-): Disulphide bond; $\left(-\mathrm{SO}_{2} \mathrm{H}\right)$ : Sulfinic acid $\left(-\mathrm{SO}_{3} \mathrm{H}\right)$ : Sulfonic acid; $\left(\mathrm{NO}^{\bullet}\right)$ : Nitric oxide radical; $\left(\mathrm{ONOO}^{-}\right)$: Peroxynitrite; RNS: Reactive nitrogen species; 3-NT: 3-nitrotyrosine; PTMs: Post translational modifications; $\mathrm{HOCl}$ : Hypochlorous acid; $\left({ }^{-} \mathrm{OOH}\right)$ : Hydroperoxide nucleophile; $(\mathrm{O}-\mathrm{O})$ : Peroxide; $\left(-\mathrm{S}^{-}\right)$: Thiolate; $(\mathrm{SN} 2)$ : Bimolecular nucleophilic substitution; (QM-MM): Quantum-classical molecular dynamics simulations; $\left(\mathrm{Ca}^{+2}\right)$ : Calcium ion; NOXs: NAD(P)H oxidases; $(\mathrm{OH})$ : Hydroxyl; OP: Oxidative potential; 4-HNE: 4-Hydroxy-2-Nonenal; $\left(\mathrm{Fe}^{+2}\right)$ : Ferrous ion; $\left(\mathrm{Fe}^{+3}\right)$ : Ferric ion; C9ORF72: Chromosome 9 open reading frame 72; FUS: RNA-binding protein fused in Sarcoma; Tg: Transgenic; Zn: Zinc; hSOD1: HumanSOD1; Km: Michaelis constant; Kcat: Turnover number of the enzyme; (Cu, E SOD): Zn deficient SOD; MalPEG: Maleimide-polyethylene glycol; ThT: Thioflavin T; SH-SY5Y: Neuroblastoma cell line; CSF: Cerebro spinal fluid. NS-shuttle: Nucleocytoplasmic shuttle; FT-MS: Fourier-transform mass spectrometry FT-MS; ECD: Electron capture dissociation; CysSOH: Cysteine sulphenic acid; HEK293: Human embryonic kidney 293 cells; NSC34: Neuroblastoma $\times$ spinal cord motor neuron cell line; $\mathrm{EC}_{50}$ : Median effective concentration; DNA: Deoxyribonucleic acid; (NFs): Neurofilaments; (GPxs): Glutathione peroxidases. 


\section{References}

1. Phaniendra, A.; Jestadi, D.B.; Periyasamy, L. Free radicals: Properties, sources, targets, and their implication in various diseases. Indian J. Clin. Biochem. 2015, 30, 11-26. [CrossRef]

2. Barber, S.C.; Mead, R.J.; Shaw, P.J. Oxidative stress in ALS: A mechanism of neurodegeneration and a therapeutic target. Biochim. Biophys. Acta 2006, 1762, 1051-1067. [CrossRef]

3. Chen, Z.; Zhong, C. Oxidative stress in Alzheimer's disease. Neurosci. Bull. 2014, 30, 271-281. [CrossRef]

4. Olanow, C.W. An introduction to the free radical hypothesis in Parkinson's disease. Ann. Neurol. 1992, 32, S2-S9. [CrossRef] [PubMed]

5. Carmo, C.; Naia, L.; Lopes, C.; Rego, A.C. Mitochondrial Dysfunction in Huntington's Disease. Adv. Exp. Med. Biol. 2018, 1049, 59-83. [PubMed]

6. Simpson, C.L.; Al-Chalabi, A. Amyotrophic lateral sclerosis as a complex genetic disease. Biochim. Biophys. Acta 2006, 1762, 973-985. [CrossRef] [PubMed]

7. Rosen, D.R.; Siddique, T.; Patterson, D.; Figlewicz, D.A.; Sapp, P.; Hentati, A.; Donaldson, D.; Goto, J.; O’Regan, J.P.; Deng, H.-X.; et al. Mutations in $\mathrm{Cu} / \mathrm{Zn}$ superoxide dismutase gene are associated with familial amyotrophic lateral sclerosis. Nature 1993, 362, 59-62. [CrossRef]

8. Paré, B.; Lehmann, M.; Beaudin, M.; Nordström, U.; Saikali, S.; Julien, J.P.; Gilthorpe, J.D.; Marklund, S.L.; Cashman, N.R.; Andersen, P.M.; et al. Misfolded SOD1 pathology in sporadic Amyotrophic Lateral Sclerosis. Sci. Rep. 2018, 8, 14223. [CrossRef] [PubMed]

9. Bunton-Stasyshyn, R.K.; Saccon, R.A.; Fratta, P.; Fisher, E.M. SOD1 Function and Its Implications for Amyotrophic Lateral Sclerosis Pathology: New and Renascent Themes. Neuroscientist 2015, 21, 519-529. [CrossRef]

10. Saccon, R.A.; Bunton-Stasyshyn, R.K.; Fisher, E.M.; Fratta, P. Is SOD1 loss of function involved in amyotrophic lateral sclerosis? Brain 2013, 136 Pt 8, 2342-2358. [CrossRef] [PubMed]

11. Rakhit, R.; Chakrabartty, A. Structure, folding, and misfolding of $\mathrm{Cu}, \mathrm{Zn}$ superoxide dismutase in amyotrophic lateral sclerosis. Biochim. Biophys. Acta 2006, 1762, 1025-1037. [CrossRef]

12. Rakhit, R.; Cunningham, P.; Furtos-Matei, A.; Dahan, S.; Qi, X.F.; Crow, J.P.; Cashman, N.R.; Kondejewski, L.H.; Chakrabartty, A Oxidation-induced misfolding and aggregation of superoxide dismutase and its implications for amyotrophic lateral sclerosis. $J$. Biol. Chem. 2002, 277, 47551-47556. [CrossRef] [PubMed]

13. Carrì, M.T.; Valle, C.; Bozzo, F.; Cozzolino, M. Oxidative stress and mitochondrial damage: Importance in non-SOD1 ALS. Front. Cell. Neurosci. 2015, 9, 41. [CrossRef] [PubMed]

14. Martins, D.; English, A.M. SOD1 oxidation and formation of soluble aggregates in yeast: Relevance to sporadic ALS development Redox Biol. 2014, 2, 632-639. [CrossRef]

15. Furukawa, Y. Pathological roles of wild-type cu, zn-superoxide dismutase in amyotrophic lateral sclerosis. Neurol. Res. Int. 2012, 2012, 323261. [CrossRef] [PubMed]

16. Petrov, D.; Daura, X.; Zagrovic, B. Effect of Oxidative Damage on the Stability and Dimerization of Superoxide Dismutase 1. Biophys. J. 2016, 110, 1499-1509. [CrossRef]

17. Gill, C.; Phelan, J.P.; Hatzipetros, T.; Kidd, J.D.; Tassinari, V.R.; Levine, B.; Wang, M.Z.; Moreno, A.; Thompson, K.; Maier, M.; et al. SOD1-positive aggregate accumulation in the CNS predicts slower disease progression and increased longevity in a mutant SOD1 mouse model of ALS. Sci. Rep. 2019, 9, 6724. [CrossRef]

18. Benkler, C.; O’Neil, A.L.; Slepian, S.; Qian, F.; Weinreb, P.H.; Rubin, L.L. Aggregated SOD1 causes selective death of cultured human motor neurons. Sci. Rep. 2018, 8, 16393. [CrossRef]

19. Bourassa, M.W.; Brown, H.H.; Borchelt, D.R.; Vogt, S.; Miller, L.M. Metal-deficient aggregates and diminished copper found in cells expressing SOD1 mutations that cause ALS. Front. Aging Neurosci. 2014, 6, 110. [CrossRef]

20. Brasil, A.A.; de Carvalho, M.D.C.; Gerhardt, E.; Queiroz, D.D.; Pereira, M.D.; Outeiro, T.F.; Eleutherio, E.C.A. Characterization of the activity, aggregation, and toxicity of heterodimers of WT and ALS-associated mutant Sod1. Proc. Natl. Acad. Sci. USA 2019, 116, 25991-26000. [CrossRef]

21. Xu, W.C.; Liang, J.Z.; Li, C.; He, Z.X.; Yuan, H.Y.; Huang, B.Y.; Liu, X.-L.; Tang, B.; Pang, D.-W.; Du, H.-N.; et al. Pathological hydrogen peroxide triggers the fibrillization of wild-type SOD1 via sulfenic acid modification of Cys-111. Cell Death Dis. 2018, 9, 67. [CrossRef]

22. Mulligan, V.K.; Kerman, A.; Laister, R.C.; Sharda, P.R.; Arslan, P.E.; Chakrabartty, A. Early steps in oxidation-induced SOD1 misfolding: Implications for non-amyloid protein aggregation in familial ALS. J. Mol. Biol. 2012, 421, 631-652. [CrossRef]

23. Yim, M.B.; Chock, P.B.; Stadtman, E.R. Copper, zinc superoxide dismutase catalyzes hydroxyl radical production from hydrogen peroxide. Proc. Natl. Acad. Sci. USA 1990, 87, 5006-5010. [CrossRef]

24. Goto, J.J.; Gralla, E.B.; Valentine, J.S.; Cabelli, D.E. Reactions of hydrogen peroxide with familial amyotrophic lateral sclerosis mutant human copper-zinc superoxide dismutases studied by pulse radiolysis. J. Biol. Chem. 1998, 273, 30104-30109. [CrossRef]

25. Valentine, J.S.; Hart, P.J. Misfolded CuZnSOD and amyotrophic lateral sclerosis. Proc. Natl. Acad. Sci. USA 2003, 100, 3617-3622. [CrossRef]

26. Jeon, G.S.; Shim, Y.M.; Lee, D.Y.; Kim, J.S.; Kang, M.; Ahn, S.H.; Shin, J.-Y.; Geum, D.; Hong, Y.-H.; Sung, J.-J. Pathological Modification of TDP-43 in Amyotrophic Lateral Sclerosis with SOD1 Mutations. Mol. Neurobiol. 2019, 56, 2007-2021. [CrossRef] [PubMed] 
27. Suk, T.R.; Rousseaux, M.W.C. The role of TDP-43 mislocalization in amyotrophic lateral sclerosis. Mol. Neurodegener. 2020, 15, 45. [CrossRef] [PubMed]

28. Volkening, K.; Leystra-Lantz, C.; Yang, W.; Jaffee, H.; Strong, M.J. Tar DNA binding protein of 43 kDa (TDP-43), 14-3-3 proteins and copper/zinc superoxide dismutase (SOD1) interact to modulate NFL mRNA stability. Implications for altered RNA processing in amyotrophic lateral sclerosis (ALS). Brain Res. 2009, 1305, 168-182. [CrossRef] [PubMed]

29. Marusawa, H.; Ichikawa, K.; Narita, N.; Murakami, H.; Ito, K.; Tezuka, T. Hydroxyl radical as a strong electrophilic species. Bioorganic Med. Chem. 2002, 10, 2283-2290. [CrossRef]

30. Forman, H.J.; Zhang, H. Targeting oxidative stress in disease: Promise and limitations of antioxidant therapy. Nat. Rev. Drug Discov. 2021, 20, 689-709. [CrossRef]

31. Sharifi-Rad, M.; Anil Kumar, N.V.; Zucca, P.; Varoni, E.M.; Dini, L.; Panzarini, E.; Rajkovic, J.; Tsouh Fokou, P.V.; Azzini, E.; Peluso, I.; et al. Lifestyle, Oxidative Stress, and Antioxidants: Back and Forth in the Pathophysiology of Chronic Diseases. Front. Physiol. 2020, 11, 694. [CrossRef] [PubMed]

32. Southorn, P.A.; Powis, G. Free radicals in medicine. I. Chemical nature and biologic reactions. Mayo Clin. Proc. 1988, 63, 381-389. [CrossRef]

33. Shields, H.J.; Traa, A.; Van Raamsdonk, J.M. Beneficial and Detrimental Effects of Reactive Oxygen Species on Lifespan: A Comprehensive Review of Comparative and Experimental Studies. Front. Cell Dev. Biol. 2021, 9, 628157. [CrossRef]

34. Borden, W.T.; Hoffmann, R.; Stuyver, T.; Chen, B. Dioxygen: What Makes This Triplet Diradical Kinetically Persistent? J. Am. Chem. Soc. 2017, 139, 9010-9018. [CrossRef] [PubMed]

35. McCord, J.M. The evolution of free radicals and oxidative stress. Am. J. Med. 2000, 108, 652-659. [CrossRef]

36. Collin, F. Chemical Basis of Reactive Oxygen Species Reactivity and Involvement in Neurodegenerative Diseases. Int. J. Mol. Sci. 2019, 20, 2407. [CrossRef]

37. Schieber, M.; Chandel, N.S. ROS function in redox signaling and oxidative stress. Curr. Biol. 2014, 24, R453-R462. [CrossRef]

38. Linnane, A.W.; Kios, M.; Vitetta, L. Coenzyme Q(10)-its role as a prooxidant in the formation of superoxide anion/hydrogen peroxide and the regulation of the metabolome. Mitochondrion 2007, 7, S51-S61. [CrossRef]

39. Beyer, R.E. An analysis of the role of coenzyme $Q$ in free radical generation and as an antioxidant. Biochem. Cell Biol. 1992, 70, 390-403. [CrossRef] [PubMed]

40. Georgieva, E.; Ivanova, D.; Zhelev, Z.; Bakalova, R.; Gulubova, M.; Aoki, I. Mitochondrial Dysfunction and Redox Imbalance as a Diagnostic Marker of "Free Radical Diseases". Anticancer Res. 2017, 37, 5373-5381.

41. Ježek, J.; Cooper, K.F.; Strich, R. Reactive Oxygen Species and Mitochondrial Dynamics: The Yin and Yang of Mitochondrial Dysfunction and Cancer Progression. Antioxidants 2018, 7, 13. [CrossRef] [PubMed]

42. Reis, A.; Spickett, C.M. Chemistry of phospholipid oxidation. Biochim. Biophys. Acta 2012, 1818, 2374-2387. [CrossRef]

43. Nissanka, N.; Moraes, C.T. Mitochondrial DNA damage and reactive oxygen species in neurodegenerative disease. FEBS Lett. 2018, 592, 728-742. [CrossRef] [PubMed]

44. Baba, S.P.; Bhatnagar, A. Role of Thiols in Oxidative Stress. Curr. Opin. Toxicol. 2018, 7, 133-139. [CrossRef]

45. Chung, H.S.; Wang, S.B.; Venkatraman, V.; Murray, C.I.; Van Eyk, J.E. Cysteine oxidative posttranslational modifications: Emerging regulation in the cardiovascular system. Circ. Res. 2013, 112, 382-392. [CrossRef]

46. He, L.; He, T.; Farrar, S.; Ji, L.; Liu, T.; Ma, X. Antioxidants Maintain Cellular Redox Homeostasis by Elimination of Reactive Oxygen Species. Cell. Physiol. Biochem. 2017, 44, 532-553. [CrossRef] [PubMed]

47. Paulsen, C.E.; Carroll, K.S. Cysteine-mediated redox signaling: Chemistry, biology, and tools for discovery. Chem. Rev. 2013, 113, 4633-4679. [CrossRef] [PubMed]

48. Trachootham, D.; Lu, W.; Ogasawara, M.A.; Nilsa, R.D.; Huang, P. Redox regulation of cell survival. Antioxid. Redox Signal. 2008, 10, 1343-1374. [CrossRef]

49. Arnold, W.P.; Mittal, C.K.; Katsuki, S.; Murad, F. Nitric oxide activates guanylate cyclase and increases guanosine 3':5'-cyclic monophosphate levels in various tissue preparations. Proc. Natl. Acad. Sci. USA 1977, 74, 3203-3207. [CrossRef] [PubMed]

50. Koppenol, W.H.; Moreno, J.J.; Pryor, W.A.; Ischiropoulos, H.; Beckman, J.S. Peroxynitrite, a cloaked oxidant formed by nitric oxide and superoxide. Chem. Res. Toxicol. 1992, 5, 834-842. [CrossRef]

51. Bandookwala, M.; Sengupta, P. 3-Nitrotyrosine: A versatile oxidative stress biomarker for major neurodegenerative diseases. Int. J. Neurosci. 2020, 130, 1047-1062. [CrossRef]

52. Beal, M.F.; Ferrante, R.J.; Browne, S.E.; Matthews, R.T.; Kowall, N.W.; Brown, R.H., Jr. Increased 3-nitrotyrosine in both sporadic and familial amyotrophic lateral sclerosis. Ann. Neurol. 1997, 42, 644-654. [CrossRef]

53. Fernández-Espejo, E.; Rodríguez de Fonseca, F.; Suárez, J.; Tolosa, E.; Vilas, D.; Aldecoa, I.; Berenguer, J.; Damas-Hermoso, F. Native $\alpha$-Synuclein, 3-Nitrotyrosine Proteins, and Patterns of Nitro- $\alpha$-Synuclein-Immunoreactive Inclusions in Saliva and Submandibulary Gland in Parkinson's Disease. Antioxidants 2021, 10, 715. [CrossRef] [PubMed]

54. Sies, H. Role of metabolic $\mathrm{H} 2 \mathrm{O} 2$ generation: Redox signaling and oxidative stress. J. Biol. Chem. 2014, 289, 8735-8741. [CrossRef]

55. Sies, H. Hydrogen peroxide as a central redox signaling molecule in physiological oxidative stress: Oxidative eustress. Redox Biol. 2017, 11, 613-619. [CrossRef]

56. Teong, S.P.; Li, X.; Zhang, Y. Hydrogen peroxide as an oxidant in biomass-to-chemical processes of industrial interest. Green Chem. 2019, 21, 5753-5780. [CrossRef] 
57. Boateng, M.K.; Price, S.L.; Huddersman, K.D.; Walsh, S.E. Antimicrobial activities of hydrogen peroxide and its activation by a novel heterogeneous Fenton's-like modified PAN catalyst. J. Appl. Microbiol. 2011, 111, 1533-1543. [CrossRef]

58. Goti, A.; Cardona, F. (Eds.) Hydrogen Peroxide in Green Oxidation Reactions: Recent Catalytic Processes; Springer: Dordrecht, The Netherlands, 2008

59. Elango, M.; Parthasarathi, R.; Subramanian, V.; Ramachandran, C.N.; Sathyamurthy, N. Hydrogen peroxide clusters: The role of open book motif in cage and helical structures. J. Phys. Chem. A 2006, 110, 6294-6300. [CrossRef]

60. Engdahl, A.; Nelander, B.; Karlström, G. A matrix isolation and ab initio study of the hydrogen peroxide dimer. J. Phys. Chem. A 2001, 105, 8393-8398. [CrossRef]

61. Winterbourn, C.C. The biological chemistry of hydrogen peroxide. Methods Enzymol. 2013, 528, 3-25.

62. Halliwell, B. Free radicals and antioxidants: Updating a personal view. Nutr. Rev. 2012, 70, 257-265. [CrossRef]

63. Winterbourn, C.C. Comparative reactivities of various biological compounds with myeloperoxidase-hydrogen peroxide-chloride, and similarity of the oxidant to hypochlorite. Biochim. Biophys. Acta 1985, 840, 204-210. [CrossRef]

64. Prütz, W.A. Hypochlorous acid interactions with thiols, nucleotides, DNA, and other biological substrates. Arch. Biochem. Biophys. 1996, 332, 110-120. [CrossRef] [PubMed]

65. Winterbourn, C.C. Reconciling the chemistry and biology of reactive oxygen species. Nat. Chem. Biol. 2008, 4, 278-286. [CrossRef]

66. Beckman, J.S.; Koppenol, W.H. Nitric oxide, superoxide, and peroxynitrite: The good, the bad, and ugly. Am. J. Physiol. 1996, 271, C1424-C1437. [CrossRef]

67. Ischiropoulos, H.; Zhu, L.; Chen, J.; Tsai, M.; Martin, J.C.; Smith, C.D.; Beckman, J.S. Peroxynitrite-mediated tyrosine nitration catalyzed by superoxide dismutase. Arch. Biochem. Biophys. 1992, 298, 431-437. [CrossRef]

68. Douki, T.; Cadet, J. Peroxynitrite mediated oxidation of purine bases of nucleosides and isolated DNA. Free Radic. Res. 1996, 24, 369-380. [CrossRef]

69. Radi, R. Oxygen radicals, nitric oxide, and peroxynitrite: Redox pathways in molecular medicine. Proc. Natl. Acad. Sci. USA 2018, 115, 5839-5848. [CrossRef]

70. Schöpfer, F.; Riobó, N.; Carreras, M.C.; Alvarez, B.; Radi, R.; Boveris, A.; Radi, R.; Boveris, A.; Cadenas, E.; Poderoso, J.J. Oxidation of ubiquinol by peroxynitrite: Implications for protection of mitochondria against nitrosative damage. Biochem. J. 2000, 349 Pt 1 , 35-42. [CrossRef] [PubMed]

71. Lipinski, B. Hydroxyl radical and its scavengers in health and disease. Oxid. Med. Cell. Longev. 2011, 2011, 809696. [CrossRef]

72. Pinto, E.; Sigaud-kutner, T.C.; Leitao, M.A.; Okamoto, O.K.; Morse, D.; Colepicolo, P. Heavy metal-induced oxidative stress in algae 1. J. Phycol. 2003, 39, 1008-1018. [CrossRef]

73. Rojanasakul, Y.; Wang, L.; Hoffman, A.H.; Shi, X.; Dalal, N.S.; Banks, D.E.; Ma, J.K.H. Mechanisms of hydroxyl free radical-induced cellular injury and calcium overloading in alveolar macrophages. Am. J. Respir. Cell Mol. Biol. 1993, 8, 377-383. [CrossRef]

74. Bach, R.D.; Ayala, P.Y.; Schlegel, H. A reassessment of the bond dissociation energies of peroxides. An ab initio study. J. Am. Chem. Soc. 1996, 118, 12758-12765. [CrossRef]

75. Behrman, E.J.; John, O.; Edwards, A. Half-Century of Peroxide Chemistry: A translation from R. Curci, L. D’Accolti, \& C. Fusco. Chim. E L'Industria 2020, 88, 32-39.

76. Chu, J.W.; Trout, B.L. On the mechanisms of oxidation of organic sulfides by $\mathrm{H}_{2} \mathrm{O}_{2}$ in aqueous solutions. J. Am. Chem. Soc. 2004, 126, 900-908. [CrossRef]

77. Cardey, B.; Enescu, M. Selenocysteine versus cysteine reactivity: A theoretical study of their oxidation by hydrogen peroxide. J. Phys. Chem. A 2007, 111, 673-678. [CrossRef] [PubMed]

78. Gupta, V.; Carroll, K.S. Profiling the Reactivity of Cyclic C-Nucleophiles towards Electrophilic Sulfur in Cysteine Sulfenic Acid. Chem. Sci. 2016, 7, 400-415. [CrossRef]

79. Zeida, A.; Babbush, R.; Lebrero, M.C.; Trujillo, M.; Radi, R.; Estrin, D.A. Molecular basis of the mechanism of thiol oxidation by hydrogen peroxide in aqueous solution: Challenging the SN2 paradigm. Chem. Res. Toxicol. 2012, 25, 741-746. [CrossRef] [PubMed]

80. Roos, G.; Foloppe, N.; Messens, J. Understanding the pK(a) of redox cysteines: The key role of hydrogen bonding. Antioxid. Redox Signal. 2013, 18, 94-127. [CrossRef]

81. Pearson, R.G.; Edgington, D.N. Nucleophilic reactivity of the hydrogen peroxide anion: Distinction between SN2 and SN1 CB mechanisms. J. Am. Chem. Soc. 1962, 84, 4607-4608. [CrossRef]

82. Brown, H.; Rao, B. Communications-selective conversion of olefins into organoboranes through competitive hydroboration, isomerization and displacement reactions. J. Org. Chem. 1957, 22, 1137-1138. [CrossRef]

83. Yim, M.B.; Yim, H.S.; Boon Chock, P.; Stadtman, E.R. Pro-oxidant activity of Cu,Zn-superoxide dismutase. Age 1998, 21, 91-93. [CrossRef]

84. Krols, M.; Bultynck, G.; Janssens, S. ER-Mitochondria contact sites: A new regulator of cellular calcium flux comes into play. J. Cell Biol. 2016, 214, 367-370. [CrossRef] [PubMed]

85. Marino, S.M.; Gladyshev, V.N. Cysteine function governs its conservation and degeneration and restricts its utilization on protein surfaces. J. Mol. Biol. 2010, 404, 902-916. [CrossRef]

86. Gülden, M.; Jess, A.; Kammann, J.; Maser, E.; Seibert, H. Cytotoxic potency of $\mathrm{H}_{2} \mathrm{O}_{2}$ in cell cultures: Impact of cell concentration and exposure time. Free Radic. Biol. Med. 2010, 49, 1298-1305. [CrossRef] [PubMed] 
87. Juarez, J.C.; Manuia, M.; Burnett, M.E.; Betancourt, O.; Boivin, B.; Shaw, D.E.; Tonks, N.K.; Mazar, A.P.; Donate, F. Superoxide dismutase 1 (SOD1) is essential for $\mathrm{H} 2 \mathrm{O} 2$-mediated oxidation and inactivation of phosphatases in growth factor signaling. Proc. Natl. Acad. Sci. USA 2008, 105, 7147-7152. [CrossRef] [PubMed]

88. Ezzi, S.A.; Urushitani, M.; Julien, J.P. Wild-type superoxide dismutase acquires binding and toxic properties of ALS-linked mutant forms through oxidation. J. Neurochem. 2007, 102, 170-178. [CrossRef]

89. Clément, M.V.; Ponton, A.; Pervaiz, S. Apoptosis induced by hydrogen peroxide is mediated by decreased superoxide anion concentration and reduction of intracellular milieu. FEBS Lett. 1998, 440, 13-18. [CrossRef]

90. Gutiérrez-Venegas, G.; Guadarrama-Solís, A.; Muñoz-Seca, C.; Arreguín-Cano, J.A. Hydrogen peroxide-induced apoptosis in human gingival fibroblasts. Int. J. Clin. Exp. Pathol. 2015, 8, 15563-15572.

91. Zhao, L.; Lin, H.; Chen, S.; Chen, S.; Cui, M.; Shi, D.; Wang, B.; Ma, K.; Shao, Z. Hydrogen peroxide induces programmed necrosis in rat nucleus pulposus cells through the RIP1/RIP3-PARP-AIF pathway. J. Orthop. Res. 2018, 36, 1269-1282. [CrossRef]

92. Halliwell, B.; Gutteridge, J.M. Free Radicals in Biology and Medicine; Oxford University Press: Oxford, UK, 2015.

93. Saito, Y.; Nishio, K.; Ogawa, Y.; Kimata, J.; Kinumi, T.; Yoshida, Y.; Noguchi, N.; Niki, E. Turning point in apoptosis/necrosis induced by hydrogen peroxide. Free Radic. Res. 2006, 40, 619-630. [CrossRef]

94. Teramoto, S.; Tomita, T.; Matsui, H.; Ohga, E.; Matsuse, T.; Ouchi, Y. Hydrogen peroxide-induced apoptosis and necrosis in human lung fibroblasts: Protective roles of glutathione. Jpn. J. Pharmacol. 1999, 79, 33-40. [PubMed]

95. Troyano, A.; Sancho, P.; Fernández, C.; de Blas, E.; Bernardi, P.; Aller, P. The selection between apoptosis and necrosis is differentially regulated in hydrogen peroxide-treated and glutathione-depleted human promonocytic cells. Cell Death Differ. 2003, 10, 889-898. [CrossRef]

96. Cookson, M.R.; Ince, P.G.; Shaw, P.J. Peroxynitrite and hydrogen peroxide induced cell death in the NSC34 neuroblastoma x spinal cord cell line: Role of poly (ADP-ribose) polymerase. J. Neurochem. 1998, 70, 501-508. [CrossRef] [PubMed]

97. Zhao, Z.Y.; Luan, P.; Huang, S.X.; Xiao, S.H.; Zhao, J.; Zhang, B.; Gu, B.-B.; Pi, R.-B.; Liu, J. Edaravone protects HT22 neurons from H2O2-induced apoptosis by inhibiting the MAPK signaling pathway. CNS Neurosci. Ther. 2013, 19, 163-169. [CrossRef] [PubMed]

98. Bian, Y.Y.; Guo, J.; Majeed, H.; Zhu, K.X.; Guo, X.N.; Peng, W.; Zhou, H.-M. Ferulic acid renders protection to HEK293 cells against oxidative damage and apoptosis induced by hydrogen peroxide. Vitr. Cell. Dev. Biol. Anim. 2015, 51, 722-729. [CrossRef]

99. Xiang, J.; Wan, C.; Guo, R.; Guo, D. Is Hydrogen Peroxide a Suitable Apoptosis Inducer for All Cell Types? Biomed. Res. Int. 2016, 2016, 7343965. [CrossRef]

100. Ali, M.A.; Kandasamy, A.D.; Fan, X.; Schulz, R. Hydrogen peroxide-induced necrotic cell death in cardiomyocytes is independent of matrix metalloproteinase-2. Toxicol. In Vitro 2013, 27, 1686-1692. [CrossRef]

101. Ohguro, N.; Fukuda, M.; Sasabe, T.; Tano, Y. Concentration dependent effects of hydrogen peroxide on lens epithelial cells. Br. J. Ophthalmol. 1999, 83, 1064-1068. [CrossRef]

102. Okuda, S.; Nishiyama, N.; Saito, H.; Katsuki, H. Hydrogen peroxide-mediated neuronal cell death induced by an endogenous neurotoxin, 3-hydroxykynurenine. Proc. Natl. Acad. Sci. USA 1996, 93, 12553-12558. [CrossRef]

103. Huang, B.K.; Sikes, H.D. Quantifying intracellular hydrogen peroxide perturbations in terms of concentration. Redox Biol. 2014, 2, 955-962. [CrossRef] [PubMed]

104. Lennicke, C.; Rahn, J.; Lichtenfels, R.; Wessjohann, L.A.; Seliger, B. Hydrogen peroxide-production, fate and role in redox signaling of tumor cells. Cell Commun. Signal. 2015, 13, 39. [CrossRef]

105. Go, Y.M.; Chandler, J.D.; Jones, D.P. The cysteine proteome. Free Radic. Biol. Med. 2015, 84, 227-245. [CrossRef]

106. Bleier, L.; Wittig, I.; Heide, H.; Steger, M.; Brandt, U.; Dröse, S. Generator-specific targets of mitochondrial reactive oxygen species. Free Radic. Biol. Med. 2015, 78, 1-10. [CrossRef]

107. Chang, C.; Worley, B.L.; Phaëton, R.; Hempel, N. Extracellular Glutathione Peroxidase GPx3 and Its Role in Cancer. Cancers 2020, 12, 2197. [CrossRef]

108. West, J.D.; Roston, T.J.; David, J.B.; Allan, K.M.; Loberg, M.A. Piecing Together How Peroxiredoxins Maintain Genomic Stability. Antioxidants 2018, 7, 177. [CrossRef]

109. Lubos, E.; Loscalzo, J.; Handy, D.E. Glutathione peroxidase-1 in health and disease: From molecular mechanisms to therapeutic opportunities. Antioxid. Redox Signal. 2011, 15, 1957-1997. [CrossRef]

110. Day, B.J. Catalase and glutathione peroxidase mimics. Biochem. Pharmacol. 2009, 77, 285-296. [CrossRef] [PubMed]

111. Fisher, A.B. Peroxiredoxin 6: A bifunctional enzyme with glutathione peroxidase and phospholipase $\mathrm{A}^{2}$ activities. Antioxid. Redox Signal. 2011, 15, 831-844. [CrossRef]

112. Wang, L.; Zhang, L.; Niu, Y.; Sitia, R.; Wang, C.C. Glutathione peroxidase 7 utilizes hydrogen peroxide generated by Ero1 $\alpha$ to promote oxidative protein folding. Antioxid. Redox Signal. 2014, 20, 545-556. [CrossRef] [PubMed]

113. Galaris, D.; Barbouti, A.; Pantopoulos, K. Iron homeostasis and oxidative stress: An intimate relationship. Biochim. Biophys. Acta Mol. Cell Res. 2019, 1866, 118535. [CrossRef] [PubMed]

114. Kaplan, J.; Ward, D.M. The essential nature of iron usage and regulation. Curr. Biol. 2013, 23, 2325. [CrossRef] [PubMed]

115. Liu, D.; Wen, J.; Liu, J.; Li, L. The roles of free radicals in amyotrophic lateral sclerosis: Reactive oxygen species and elevated oxidation of protein, DNA, and membrane phospholipids. FASEB J. 1999, 13, 2318-2328. [CrossRef]

116. Bu, X.L.; Xiang, Y.; Guo, Y. The Role of Iron in Amyotrophic Lateral Sclerosis. Adv. Exp. Med. Biol. 2019, 1173, 145-152. [PubMed]

117. Piñero, D.J.; Connor, J.R. Iron in the brain: An important contributor in normal and diseased states. Neuroscientist 2000, 6, 435-453. [CrossRef] 
118. McCann, S.; Perapoch Amadó, M.; Moore, S.E. The Role of Iron in Brain Development: A Systematic Review. Nutrients 2020, 12, 2001. [CrossRef]

119. Ward, R.J.; Zucca, F.A.; Duyn, J.H.; Crichton, R.R.; Zecca, L. The role of iron in brain ageing and neurodegenerative disorders. Lancet Neurol. 2014, 13, 1045-1060. [CrossRef]

120. Ndayisaba, A.; Kaindlstorfer, C.; Wenning, G.K. Iron in Neurodegeneration-Cause or Consequence? Front. Neurosci. 2019, 13, 180. [CrossRef]

121. Ince, P.G.; Shaw, P.J.; Candy, J.M.; Mantle, D.; Tandon, L.; Ehmann, W.D.; Markesbery, W. Iron, selenium and glutathione peroxidase activity are elevated in sporadic motor neuron disease. Neurosci. Lett. 1994, 182, 87-90. [CrossRef]

122. Ignjatović, A.; Stević, Z.; Lavrnić, S.; Daković, M.; Bačić, G. Brain iron MRI: A biomarker for amyotrophic lateral sclerosis. J. Magn. Reson. Imaging 2013, 38, 1472-1479. [CrossRef]

123. Yasui, M.; Ota, K.; Garruto, R.M. Concentrations of zinc and iron in the brains of Guamanian patients with amyotrophic lateral sclerosis and parkinsonism-dementia. Neurotoxicology 1993, 14, 445-450.

124. Veyrat-Durebex, C.; Corcia, P.; Mucha, A.; Benzimra, S.; Mallet, C.; Gendrot, C.; Moreau, C.; Devos, D.; Piver, E.; Pages, J.-C.; et al Iron metabolism disturbance in a French cohort of ALS patients. Biomed. Res. Int. 2014, 2014, 485723. [CrossRef]

125. Zheng, Y.; Gao, L.; Wang, D.; Zang, D. Elevated levels of ferritin in the cerebrospinal fluid of amyotrophic lateral sclerosis patients. Acta Neurol. Scand. 2017, 136, 145-150. [CrossRef]

126. Popović-Bijelić, A.; Mojović, M.; Stamenković, S.; Jovanović, M.; Selaković, V.; Andjus, P.; Bačić, G. Iron-sulfur cluster damage by the superoxide radical in neural tissues of the SOD1(G93A) ALS rat model. Free Radic. Biol. Med. 2016, 96, 313-322. [CrossRef]

127. Sheykhansari, S.; Kozielski, K.; Bill, J.; Sitti, M.; Gemmati, D.; Zamboni, P.; Singh, A.V. Redox metals homeostasis in multiple sclerosis and amyotrophic lateral sclerosis: A review. Cell Death Dis. 2018, 9, 348. [CrossRef]

128. Bozzo, F.; Mirra, A.; Carrì, M.T. Oxidative stress and mitochondrial damage in the pathogenesis of ALS: New perspectives. Neurosci. Lett. 2017, 636, 3-8. [CrossRef] [PubMed]

129. Winterbourn, C.C. Toxicity of iron and hydrogen peroxide: The Fenton reaction. Toxicol. Lett. 1995, 82-83, 969-974. [CrossRef]

130. Cadet, J.; Delatour, T.; Douki, T.; Gasparutto, D.; Pouget, J.P.; Ravanat, J.L.; Sauvaigo, S. Hydroxyl radicals and DNA base damage. Mutat. Res. 1999, 424, 9-21. [CrossRef]

131. Uchida, K.; Kawakishi, S. 2-Oxo-histidine as a novel biological marker for oxidatively modified proteins. FEBS Lett. 1993, 332, 208-210. [CrossRef]

132. Schöneich, C.; Pogocki, D.; Hug, G.L.; Bobrowski, K. Free radical reactions of methionine in peptides: Mechanisms relevant to beta-amyloid oxidation and Alzheimer's disease. J. Am. Chem. Soc. 2003, 125, 13700-13713. [CrossRef]

133. Masuda, T.; Shinohara, H.; Eda, M.; Kondo, M. Reactivity of nucleotides and polynucleotides toward hydroxyl radical in aqueous solution. J. Radiat. Res. 1980, 21, 173-179. [CrossRef]

134. Gardner, H.W. Oxygen radical chemistry of polyunsaturated fatty acids. Free Radic. Biol. Med. 1989, 7, 65-86. [CrossRef]

135. Stadtman, E.R. Protein oxidation in aging and age-related diseases. Ann. N. Y. Acad. Sci. 2001, 928, 22-38. [CrossRef] [PubMed]

136. Ramana, K.V.; Srivastava, S.; Singhal, S.S. Lipid peroxidation products in human health and disease 2014. Oxid. Med. Cell. Longev. 2014, 2014, 162414. [CrossRef]

137. Kehrer, J.P. The Haber-Weiss reaction and mechanisms of toxicity. Toxicology 2000, 149, 43-50. [CrossRef]

138. Shen, J.; Griffiths, P.T.; Campbell, S.J.; Utinger, B.; Kalberer, M.; Paulson, S.E. Ascorbate oxidation by iron, copper and reactive oxygen species: Review, model development, and derivation of key rate constants. Sci. Rep. 2021, 11, 7417. [CrossRef]

139. Timoshnikov, V.A.; Kobzeva, T.V.; Polyakov, N.E.; Kontoghiorghes, G.J. Redox Interactions of Vitamin C and Iron: Inhibition of the Pro-Oxidant Activity by Deferiprone. Int. J. Mol. Sci. 2020, 21, 3967. [CrossRef]

140. Brown, R.H.; Al-Chalabi, A. Amyotrophic Lateral Sclerosis. N. Engl. J. Med. 2017, 377, 162-172. [CrossRef]

141. Zarei, S.; Carr, K.; Reiley, L.; Diaz, K.; Guerra, O.; Altamirano, P.F.; Pagani, W.; Lodin, D.; Orozco, G.; Chinea, A. A comprehensive review of amyotrophic lateral sclerosis. Surg. Neurol. Int. 2015, 6, 171. [CrossRef] [PubMed]

142. Wolf, J.; Safer, A.; Wöhrle, J.C.; Palm, F.; Nix, W.A.; Maschke, M.; Grau, A.J. Factors predicting one-year mortality in amyotrophic lateral sclerosis patients-data from a population-based registry. BMC Neurol. 2014, 14, 197. [CrossRef]

143. Román, G.C. Neuroepidemiology of amyotrophic lateral sclerosis: Clues to aetiology and pathogenesis. J. Neurol. Neurosurg. Psychiatry 1996, 61, 131-137. [CrossRef]

144. Longinetti, E.; Regodón Wallin, A.; Samuelsson, K.; Press, R.; Zachau, A.; Ronnevi, L.O.; Kierkegaard, M.; Andersen, P.M.; Hillert, J.; Fang, F.; et al. The Swedish motor neuron disease quality registry. Amyotroph Lateral Scler. Front. Degener. 2018, 19, 528-537. [CrossRef]

145. Palese, F.; Sartori, A.; Verriello, L.; Ros, S.; Passadore, P.; Manganotti, P.; Barbone, F.; Pisa, F.E. Epidemiology of amyotrophic lateral sclerosis in Friuli-Venezia Giulia, North-Eastern Italy, 2002-2014: A retrospective population-based study. Amyotroph Lateral Scler. Front. Degener. 2019, 20, 90-99. [CrossRef]

146. Rose, L.; McKim, D.; Leasa, D.; Nonoyama, M.; Tandon, A.; Bai, Y.Q.; Amin, R.; Katz, S.; Goldstein, R.; Gershon, A. Trends in incidence, prevalence, and mortality of neuromuscular disease in Ontario, Canada: A population-based retrospective cohort study (2003-2014). PLoS ONE 2019, 14, e0210574. [CrossRef] [PubMed]

147. Zhou, S.; Zhou, Y.; Qian, S.; Chang, W.; Wang, L.; Fan, D. Amyotrophic lateral sclerosis in Beijing: Epidemiologic features and prognosis from 2010 to 2015. Brain Behav. 2018, 8, e01131. [CrossRef] [PubMed] 
148. Nelson, L.M.; Topol, B.; Kaye, W.; Williamson, D.; Horton, D.K.; Mehta, P.; Wagner, T. Estimation of the Prevalence of Amyotrophic Lateral Sclerosis in the United States Using National Administrative Healthcare Data from 2002 to 2004 and Capture-Recapture Methodology. Neuroepidemiology 2018, 51, 149-157. [CrossRef]

149. Nakken, O.; Lindstrøm, J.C.; Tysnes, O.B.; Holmøy, T. Assessing amyotrophic lateral sclerosis prevalence in Norway from 2009 to 2015 from compulsory nationwide health registers. Amyotroph Lateral Scler. Front. Degener. 2018, 19, 303-310. [CrossRef] [PubMed]

150. Mehta, P.; Kaye, W.; Raymond, J.; Punjani, R.; Larson, T.; Cohen, J.; Muravov, O.; Horton, K. Prevalence of Amyotrophic Lateral Sclerosis-United States, 2015. MMWR Morb. Mortal Wkly. Rep. 2018, 67, 1285-1289. [CrossRef]

151. Longinetti, E.; Fang, F. Epidemiology of amyotrophic lateral sclerosis: An update of recent literature. Curr. Opin. Neurol. 2019, 32, 771-776. [CrossRef] [PubMed]

152. Mejzini, R.; Flynn, L.L.; Pitout, I.L.; Fletcher, S.; Wilton, S.D.; Akkari, P.A. ALS Genetics, Mechanisms, and Therapeutics: Where Are We Now? Front. Neurosci. 2019, 13, 1310. [CrossRef]

153. Mathis, S.; Goizet, C.; Soulages, A.; Vallat, J.M.; Masson, G.L. Genetics of amyotrophic lateral sclerosis: A review. J. Neurol. Sci. 2019, 399, 217-226. [CrossRef]

154. Kabashi, E.; Valdmanis, P.N.; Dion, P.; Rouleau, G.A. Oxidized/misfolded superoxide dismutase-1: The cause of all amyotrophic lateral sclerosis? Ann. Neurol. 2007, 62, 553-559. [CrossRef]

155. Bosco, D.A.; Landers, J.E. Genetic determinants of amyotrophic lateral sclerosis as therapeutic targets. CNS Neurol. Disord. Drug Targets 2010, 9, 779-790. [CrossRef]

156. Orrell, R.W. Amyotrophic lateral sclerosis: Copper/zinc superoxide dismutase (SOD1) gene mutations. Neuromuscul. Disord. 2000, 10, 63-68. [CrossRef]

157. Andersen, P.M. Amyotrophic lateral sclerosis associated with mutations in the CuZn superoxide dismutase gene. Curr. Neurol. Neurosci. Rep. 2006, 6, 37-46. [CrossRef]

158. Rotunno, M.S.; Bosco, D.A. An emerging role for misfolded wild-type SOD1 in sporadic ALS pathogenesis. Front. Cell. Neurosci. 2013, 7, 253. [CrossRef]

159. Balendra, R.; Isaacs, A.M. C9orf72-mediated ALS and FTD: Multiple pathways to disease. Nat. Rev. Neurol. 2018, 14, 544-558. [CrossRef]

160. Birsa, N.; Bentham, M.P.; Fratta, P. Cytoplasmic functions of TDP-43 and FUS and their role in ALS. Semin. Cell Dev. Biol. 2020, 99 , 193-201. [CrossRef] [PubMed]

161. Prasad, A.; Bharathi, V.; Sivalingam, V.; Girdhar, A.; Patel, B.K. Molecular Mechanisms of TDP-43 Misfolding and Pathology in Amyotrophic Lateral Sclerosis. Front. Mol. Neurosci. 2019, 12, 25. [CrossRef]

162. Forsberg, K.; Andersen, P.M.; Marklund, S.L.; Brännström, T. Glial nuclear aggregates of superoxide dismutase-1 are regularly present in patients with amyotrophic lateral sclerosis. Acta Neuropathol. 2011, 121, 623-634. [CrossRef] [PubMed]

163. Gurney, M.E.; Pu, H.; Chiu, A.Y.; Dal Canto, M.C.; Polchow, C.Y.; Alexander, D.D.; Caliendo, J.; Hentati, A.; Kwon, Y.W.; Deng, H.X.; et al. Motor neuron degeneration in mice that express a human $\mathrm{Cu}, \mathrm{Zn}$ superoxide dismutase mutation. Science 1994, 264, 1772-1775. [CrossRef] [PubMed]

164. Wong, P.C.; Pardo, C.A.; Borchelt, D.R.; Lee, M.K.; Copeland, N.G.; Jenkins, N.A.; Sisodia, S.S.; Cleveland, D.; Price, D.L. An adverse property of a familial ALS-linked SOD1 mutation causes motor neuron disease characterized by vacuolar degeneration of mitochondria. Neuron 1995, 14, 1105-1116. [CrossRef]

165. Bruijn, L.I.; Becher, M.W.; Lee, M.K.; Anderson, K.L.; Jenkins, N.A.; Copeland, N.G.; Sisodia, S.S.; Rothstein, J.D.; Borchelt, D.R.; Price, D.L.; et al. ALS-linked SOD1 mutant G85R mediates damage to astrocytes and promotes rapidly progressive disease with SOD1-containing inclusions. Neuron 1997, 18, 327-338. [CrossRef]

166. Wiedau-Pazos, M.; Goto, J.J.; Rabizadeh, S.; Gralla, E.B.; Roe, J.A.; Lee, M.K.; Valentine, J.S.; Bredesen, D.E. Altered reactivity of superoxide dismutase in familial amyotrophic lateral sclerosis. Science 1996, 271, 515-518. [CrossRef]

167. Wang, J.; Xu, G.; Li, H.; Gonzales, V.; Fromholt, D.; Karch, C.; Valentine, J.S.; Bredesen, D.E. Somatodendritic accumulation of misfolded SOD1-L126Z in motor neurons mediates degeneration: $\alpha \mathrm{B}$-crystallin modulates aggregation. Hum. Mol. Genet. 2005, 14, 2335-2347. [CrossRef] [PubMed]

168. Jonsson, P.A.; Graffmo, K.S.; Andersen, P.M.; Brännström, T.; Lindberg, M.; Oliveberg, M.; Marklund, S.L. Disulphide-reduced superoxide dismutase-1 in CNS of transgenic amyotrophic lateral sclerosis models. Brain 2006, 129 Pt 2, 451-464. [CrossRef]

169. Julien, J.P.; Kriz, J. Transgenic mouse models of amyotrophic lateral sclerosis. Biochim. Biophys. Acta 2006, 1762, 1013-1024. [CrossRef]

170. De Giorgio, F.; Maduro, C.; Fisher, E.M.C.; Acevedo-Arozena, A. Transgenic and physiological mouse models give insights into different aspects of amyotrophic lateral sclerosis. Dis. Model Mech. 2019, 12, dmm037424. [CrossRef]

171. Zelko, I.N.; Mariani, T.J.; Folz, R.J. Superoxide dismutase multigene family: A comparison of the CuZn-SOD (SOD1), Mn-SOD (SOD2), and EC-SOD (SOD3) gene structures, evolution, and expression. Free Radic. Biol. Med. 2002, 33, 337-349. [CrossRef]

172. Fukai, T.; Ushio-Fukai, M. Superoxide dismutases: Role in redox signaling, vascular function, and diseases. Antioxid. Redox Signal. 2011, 15, 1583-1606. [CrossRef]

173. Pardo, C.A.; Xu, Z.; Borchelt, D.R.; Price, D.L.; Sisodia, S.S.; Cleveland, D.W. Superoxide dismutase is an abundant component in cell bodies, dendrites, and axons of motor neurons and in a subset of other neurons. Proc. Natl. Acad. Sci. USA 1995, 92, 954-958. [CrossRef] 
174. Furukawa, Y.; Torres, A.S.; O'Halloran, T.V. Oxygen-induced maturation of SOD1: A key role for disulfide formation by the copper chaperone CCS. EMBO J. 2004, 23, 2872-2881. [CrossRef]

175. Lepock, J.R.; Arnold, L.D.; Torrie, B.H.; Andrews, B.; Kruuv, J. Structural analyses of various $\mathrm{Cu}^{2+}, \mathrm{Zn}^{2+}$-superoxide dismutases by differential scanning calorimetry and Raman spectroscopy. Arch. Biochem. Biophys. 1985, 241, 243-251. [CrossRef]

176. Tainer, J.A.; Getzoff, E.D.; Richardson, J.S.; Richardson, D.C. Structure and mechanism of copper, zinc superoxide dismutase. Nature 1983, 306, 284-287. [CrossRef]

177. Tainer, J.A.; Getzoff, E.D.; Beem, K.M.; Richardson, J.S.; Richardson, D.C. Determination and analysis of the 2 A-structure of copper, zinc superoxide dismutase. J. Mol. Biol. 1982, 160, 181-217. [CrossRef]

178. Kayatekin, C.; Zitzewitz, J.A.; Matthews, C.R. Zinc binding modulates the entire folding free energy surface of human Cu,Zn superoxide dismutase. J. Mol. Biol. 2008, 384, 540-555. [CrossRef]

179. Dafforn, T.R.; Smith, C.J. Natively unfolded domains in endocytosis: Hooks, lines and linkers. EMBO Rep. 2004, 5, 1046-1052. [CrossRef]

180. Anzai, I.; Tokuda, E.; Handa, S.; Misawa, H.; Akiyama, S.; Furukawa, Y. Oxidative misfolding of Cu/Zn-superoxide dismutase triggered by non-canonical intramolecular disulfide formation. Free Radic. Biol. Med. 2020, 147, 187-199. [CrossRef]

181. Cleveland, D.W.; Liu, J. Oxidation versus aggregation-how do SOD1 mutants cause ALS? Nat. Med. 2000, 6, 1320-1321. [CrossRef]

182. Jewett, S.L.; Rocklin, A.M.; Ghanevati, M.; Abel, J.M.; Marach, J.A. A new look at a time-worn system: Oxidation of CuZn-SOD by $\mathrm{H}_{2} \mathrm{O}_{2}$. Free Radic. Biol. Med. 1999, 26, 905-918. [CrossRef]

183. Sampson, J.B.; Beckman, J.S. Hydrogen peroxide damages the zinc-binding site of zinc-deficient $\mathrm{Cu}, \mathrm{Zn}$ superoxide dismutase. Arch. Biochem. Biophys. 2001, 392, 8-13. [CrossRef]

184. Seetharaman, S.V.; Winkler, D.D.; Taylor, A.B.; Cao, X.; Whitson, L.J.; Doucette, P.A.; Valentine, J.S.; Schirf, V.; Demeler, B.; Carroll, M.C.; et al. Disrupted zinc-binding sites in structures of pathogenic SOD1 variants D124V and H80R. Biochemistry 2010, 49, 5714-5725. [CrossRef]

185. Li, H.T.; Jiao, M.; Chen, J.; Liang, Y. Roles of zinc and copper in modulating the oxidative refolding of bovine copper, zinc superoxide dismutase. Acta Biochim. Biophys. Sin. 2010, 42, 183-194. [CrossRef]

186. Boyd, S.D.; Ullrich, M.S.; Calvo, J.S.; Behnia, F.; Meloni, G.; Winkler, D.D. Mutations in Superoxide Dismutase 1 (Sod1) Linked to Familial Amyotrophic Lateral Sclerosis Can Disrupt High-Affinity Zinc-Binding Promoted by the Copper Chaperone for Sod1 (Ccs). Molecules 2020, 25, 1086. [CrossRef]

187. Mendonça, D.M.; Chimelli, L.; Martinez, A.M. Quantitative evidence for neurofilament heavy subunit aggregation in motor neurons of spinal cords of patients with amyotrophic lateral sclerosis. Braz. J. Med. Biol. Res. 2005, 38, 925-933. [CrossRef]

188. Zucchi, E.; Bonetto, V.; Sorarù, G.; Martinelli, I.; Parchi, P.; Liguori, R.; Mandrioli, J. Neurofilaments in motor neuron disorders: Towards promising diagnostic and prognostic biomarkers. Mol. Neurodegener. 2020, 15, 58. [CrossRef]

189. Falzone, Y.M.; Russo, T.; Domi, T.; Pozzi, L.; Quattrini, A.; Filippi, M. Current application of neurofilaments in amyotrophic lateral sclerosis and future perspectives. Neural Regen. Res. 2021, 16, 1985-1991.

190. Pierson, K.B.; Evenson, M.A. 200 Kd neurofilament protein binds Al, Cu and Zn. Biochem. Biophys. Res. Commun. 1988, 152, 598-604. [CrossRef]

191. Crow, J.P.; Sampson, J.B.; Zhuang, Y.; Thompson, J.A.; Beckman, J.S. Decreased zinc affinity of amyotrophic lateral sclerosisassociated superoxide dismutase mutants leads to enhanced catalysis of tyrosine nitration by peroxynitrite. J. Neurochem. 1997, 69, 1936-1944. [CrossRef]

192. Crow, J.P.; Ye, Y.Z.; Strong, M.; Kirk, M.; Barnes, S.; Beckman, J.S. Superoxide dismutase catalyzes nitration of tyrosines by peroxynitrite in the rod and head domains of neurofilament-L. J. Neurochem. 1997, 69, 1945-1953. [CrossRef]

193. Gaggelli, E.; Kozlowski, H.; Valensin, D.; Valensin, G. Copper homeostasis and neurodegenerative disorders (Alzheimer's, prion, and Parkinson's diseases and amyotrophic lateral sclerosis). Chem. Rev. 2006, 106, 1995-2044. [CrossRef] [PubMed]

194. Roberts, B.R.; Lim, N.K.; McAllum, E.J.; Donnelly, P.S.; Hare, D.J.; Doble, P.A.; Turner, B.J.; Price, K.A.; Lim, S.C.; Paterson, B.M.; et al. Oral treatment with $\mathrm{Cu}(\mathrm{II})($ atsm) increases mutant SOD1 in vivo but protects motor neurons and improves the phenotype of a transgenic mouse model of amyotrophic lateral sclerosis. J. Neurosci. 2014, 34, 8021-8031. [CrossRef] [PubMed]

195. Nikseresht, S.; Hilton, J.B.W.; Kysenius, K.; Liddell, J.R.; Crouch, P.J. Copper-ATSM as a Treatment for ALS: Support from Mutant SOD1 Models and Beyond. Life 2020, 10, 271. [CrossRef]

196. Kurahashi, T.; Miyazaki, A.; Suwan, S.; Isobe, M. Extensive investigations on oxidized amino acid residues in $\mathrm{H}(2) \mathrm{O}(2)$-treated $\mathrm{Cu}, \mathrm{Zn}-\mathrm{SOd}$ protein with LC-ESI-Q-TOF-MS, MS/MS for the determination of the copper-binding site. J. Am. Chem. Soc. 2001, 123, 9268-9278. [CrossRef] [PubMed]

197. Hodgson, E.K.; Fridovich, I. The interaction of bovine erythrocyte superoxide dismutase with hydrogen peroxide: Inactivation of the enzyme. Biochemistry 1975, 14, 5294-5299. [CrossRef]

198. Hough, M.A.; Grossmann, J.G.; Antonyuk, S.V.; Strange, R.W.; Doucette, P.A.; Rodriguez, J.A.; Whitson, L.J.; Hart, P.J.; Hayward, L.J.; Valentine, J.S.; et al. Dimer destabilization in superoxide dismutase may result in disease-causing properties: Structures of motor neuron disease mutants. Proc. Natl. Acad. Sci. USA 2004, 101, 5976-5981. [CrossRef]

199. Arnesano, F.; Banci, L.; Bertini, I.; Martinelli, M.; Furukawa, Y.; O’Halloran, T.V. The unusually stable quaternary structure of human $\mathrm{Cu}, \mathrm{Zn}$-superoxide dismutase 1 is controlled by both metal occupancy and disulfide status. J. Biol. Chem. 2004, 279, 47998-48003. [CrossRef] 
200. Lynch, S.M.; Boswell, S.A.; Colón, W. Kinetic stability of $\mathrm{Cu} / \mathrm{Zn}$ superoxide dismutase is dependent on its metal ligands: Implications for ALS. Biochemistry 2004, 43, 16525-16531. [CrossRef]

201. Julien, J.P. Amyotrophic lateral sclerosis. unfolding the toxicity of the misfolded. Cell 2001, 104, 581-591. [CrossRef]

202. Coelho, F.R.; Iqbal, A.; Linares, E.; Silva, D.F.; Lima, F.S.; Cuccovia, I.M.; Augusto, O. Oxidation of the tryptophan 32 residue of human superoxide dismutase 1 caused by its bicarbonate-dependent peroxidase activity triggers the non-amyloid aggregation of the enzyme. J. Biol. Chem. 2014, 289, 30690-30701. [CrossRef]

203. Graffmo, K.S.; Forsberg, K.; Bergh, J.; Birve, A.; Zetterström, P.; Andersen, P.M.; Marklund, S.L.; Brännström, T. Expression of wild-type human superoxide dismutase-1 in mice causes amyotrophic lateral sclerosis. Hum. Mol. Genet. 2013, 22, 51-60. [CrossRef] [PubMed]

204. Guareschi, S.; Cova, E.; Cereda, C.; Ceroni, M.; Donetti, E.; Bosco, D.A.; Trotti, D.; Pasinelli, P. An over-oxidized form of superoxide dismutase found in sporadic amyotrophic lateral sclerosis with bulbar onset shares a toxic mechanism with mutant SOD1. Proc. Natl. Acad. Sci. USA 2012, 109, 5074-5079. [CrossRef]

205. Bakavayev, S.; Chetrit, N.; Zvagelsky, T.; Mansour, R.; Vyazmensky, M.; Barak, Z.; Israelson, A.; Engel, S. Cu/Zn-superoxide dismutase and wild-type like fALS SOD1 mutants produce cytotoxic quantities of $\mathrm{H}(2) \mathrm{O}(2)$ via cysteine-dependent redox short-circuit. Sci. Rep. 2019, 9, 10826. [CrossRef]

206. Fujiwara, N.; Nakano, M.; Kato, S.; Yoshihara, D.; Ookawara, T.; Eguchi, H.; Taniguchi, N.; Suzuki, K. Oxidative modification to cysteine sulfonic acid of Cys111 in human copper-zinc superoxide dismutase. J. Biol. Chem. 2007, 282, 35933-35944. [CrossRef] [PubMed]

207. De Beus, M.D.; Chung, J.; Colón, W. Modification of cysteine 111 in Cu/Zn superoxide dismutase results in altered spectroscopic and biophysical properties. Protein Sci. 2004, 13, 1347-1355. [CrossRef] [PubMed]

208. Chen, X.; Shang, H.; Qiu, X.; Fujiwara, N.; Cui, L.; Li, X.M.; Gao, T.-M.; Kong, J. Oxidative modification of cysteine 111 promotes disulfide bond-independent aggregation of SOD1. Neurochem. Res. 2012, 37, 835-845. [CrossRef]

209. Shafiq, K.; Sanghai, N.; Guo, Y.; Kong, J. Implication of post-translationally modified SOD1 in pathological aging. Geroscience 2021, 43, 507-515. [CrossRef] [PubMed]

210. Bosco, D.A.; Morfini, G.; Karabacak, N.M.; Song, Y.; Gros-Louis, F.; Pasinelli, P.; Goolsby, H.; A Fontaine, B.; Lemay, N.; McKennaYasek, D.; et al. Wild-type and mutant SOD1 share an aberrant conformation and a common pathogenic pathway in ALS. Nat. Neurosci. 2010, 13, 1396-1403. [CrossRef]

211. Strange, R.W.; Antonyuk, S.V.; Hough, M.A.; Doucette, P.A.; Valentine, J.S.; Hasnain, S.S. Variable metallation of human superoxide dismutase: Atomic resolution crystal structures of $\mathrm{Cu}-\mathrm{Zn}, \mathrm{Zn}-\mathrm{Zn}$ and as-isolated wild-type enzymes. J. Mol. Biol. 2006, 356, 1152-1162. [CrossRef]

212. Cohen, T.J.; Hwang, A.W.; Unger, T.; Trojanowski, J.Q.; Lee, V.M. Redox signalling directly regulates TDP-43 via cysteine oxidation and disulphide cross-linking. EMBO J. 2012, 31, 1241-1252. [CrossRef]

213. Pokrishevsky, E.; Grad, L.I.; Yousefi, M.; Wang, J.; Mackenzie, I.R.; Cashman, N.R. Aberrant localization of FUS and TDP43 is associated with misfolding of SOD1 in amyotrophic lateral sclerosis. PLoS ONE 2012, 7, e35050. [CrossRef]

214. Jiang, L.L.; Che, M.X.; Zhao, J.; Zhou, C.J.; Xie, M.Y.; Li, H.Y.; He, J.-H.; Hu, H.-Y. Structural transformation of the amyloidogenic core region of TDP-43 protein initiates its aggregation and cytoplasmic inclusion. J. Biol. Chem. 2013, 288, 19614-19624. [CrossRef]

215. Robinson, J.L.; Geser, F.; Stieber, A.; Umoh, M.; Kwong, L.K.; Van Deerlin, V.M.; Lee, V.M.-Y.; Trojanowski, J.Q. TDP-43 skeins show properties of amyloid in a subset of ALS cases. Acta Neuropathol. 2013, 125, 121-131. [CrossRef]

216. Chang, C.K.; Chiang, M.H.; Toh, E.K.; Chang, C.F.; Huang, T.H. Molecular mechanism of oxidation-induced TDP-43 RRM1 aggregation and loss of function. FEBS Lett. 2013, 587, 575-582. [CrossRef]

217. Lin, Y.; Zhou, X.; Kato, M.; Liu, D.; Ghaemmaghami, S.; Tu, B.P.; McKnight, S.L. Redox-mediated regulation of an evolutionarily conserved cross- $\beta$ structure formed by the TDP43 low complexity domain. Proc. Natl. Acad. Sci. USA 2020, 117, 28727-28734. [CrossRef]

218. Wood, A.; Gurfinkel, Y.; Polain, N.; Lamont, W.; Lyn Rea, S. Molecular Mechanisms Underlying TDP-43 Pathology in Cellular and Animal Models of ALS and FTLD. Int. J. Mol. Sci. 2021, 22, 4705. [CrossRef] 